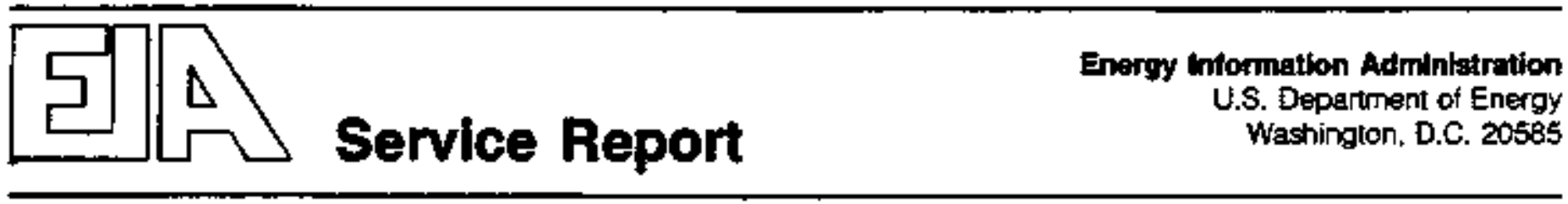

SR/OIAF(96-04)

The Impacts on U.S. Energy

Markets and the Economy of Reducing Oil Imports

RECEIVED

JAN 16 1997

OSTI

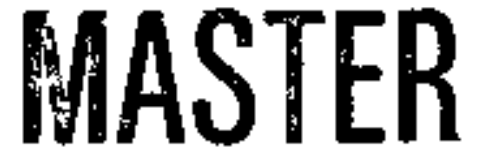

September 1996 
Released for Printing: September 24, 1996 


\title{
Service Report
}

\section{The Impacts on US. Energy Markets and the Economy of Reducing Oil Imports}

\author{
Prepared by \\ Office of Integrated Analysis and Forecasting \\ Energy Information Administration \\ U.S. Department of Energy
}

For

The General Accounting Office

September 1996

Service Reports are prepared by EIA upon special request and may be based on assumptions specified by the requestor. Information.

regarding the request for this report is included in the Preface. 


\section{DISCLANMTR}

Portions of this documeat may be illeglble in electronic image products. Images are produced from the best avallable original document. 


\section{DECLAIMER}

This report wa piepared 4 an acsount of work sposered by an agency of the Unilted States Gowstament Neviher the Untied States Government wor any arescy

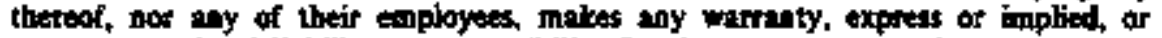

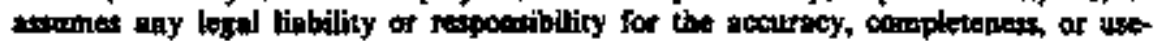
fulness of any information, eppardats product, or process diackied, or represents that its we would not infringe privntely owned rights. Reference herein to awy spo. sific commetrial produce, process, or service by track nsms, trademark, manulac.

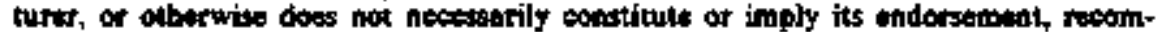

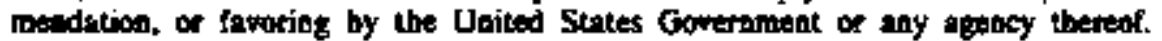
The views and opinians of authar expresped herein do not mecessifily state $\alpha$ refiect those of the United Suates Goremment of any azency thereof. 


\section{For Further Information...}

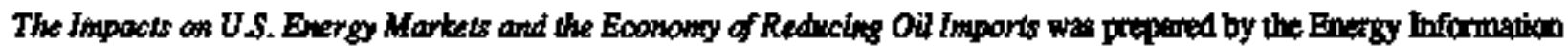
Administration (ElA), Office of Integrated Analysis and Forecasting, undin the ditrection of Mary J. flutzler

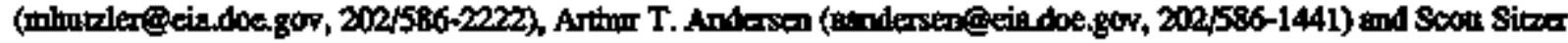

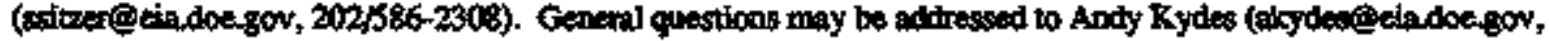
202/586-2222), Semior Teclmical Advisor and Project Divectar, or Ron Earley (rearleyeleidodoesov, 202/586-1398), Deputy Project Director. Detsiled questions about the forecests and analysis may be adteressed to the following angilysts:

Demand Analysis

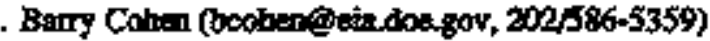

mbernational Oil Markets

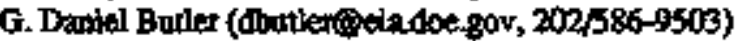

Macroeconomic \& Sectorat Ansysis Ron Exley (rearley Qeiadoe,gow, 2025\%6-1398)

$\ldots \ldots \ldots \ldots \ldots \ldots$ Xay A. Snilith (ksmith@ein doe gov, 202/586-1455)

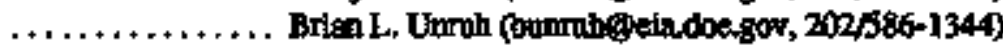

Namral Gas Markets

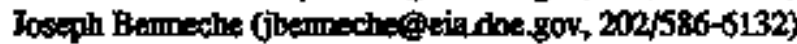

Oil and Gas Mertets Jemes Kerdell (jeendell@etadoengov, 202/586-9646)

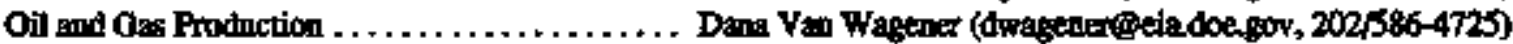

Refinery Production Thorras White (twhite@eiadoegov, 201586-1393)

The Impacts on U.S. Bnarty Martets and the Economy of Reducing Oil Imports Energ Information Administration, September 19\%6 


\section{Preface}

This study was madertaken at the request of the Goneral Accounting Office (GAO). Its purpose is to evaluate the impacts on U.S. energy markets and the economy of reducing oil imports. The approach and assumptions underlying this report were specified by GAO and are attached as an Appendix. The study focuses on two approaches: (1) a set of cases with alternative world crude oil price trajectories and (2) two cases which investigate the use of an oil import tariff to achieve a target reduction in the oil imports. The analysis presented uses the National Energy Modeling System, which is maintained by the Office of Integrated Analysis and Forecasting within the Energy Information Administration (EIA), and the DRIMAGraw Fill Macroeconomic Model of the U.S. Economy, a proprietary model maintained by DRI and subscribed to by EIA.

The National Energy Modeling System (NEMS) is an integrated energy-economy modeling system for U.S. energy matkets, developed by the EIA as a policy analysis tool to provide an integrated framework for policymaleers to understand the implications of proposed policies and alternative assumptions concerning energy markets. NEMS is nsed anmually by EIA's Office of Integrated Analysis and Forocasting (OIAF) to produce a Reference Case and a range of alternative projections for the midterm future, which are published in the Amnnal Enexgy Outhook. The Amnnal. Energy Ontlook 1996 (AEO96), published in January 1996, projects energy trends to the year 2015. While the furure entails many uncertainties, the $A E O 96$ Reference Case reflects EIA's assessment of the most likely direction of U.S. energy indicators. The Reference Case assumes that current laws and regulatory policies will continue into the fature.

This analysis should not be construed as advocating or reflecting any policy position of the U.S. Department of Energy or the Energy Information Administration. 


\section{Contents}

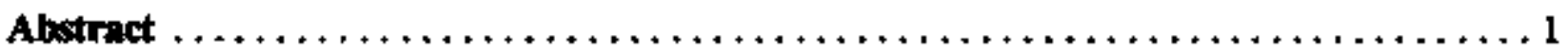

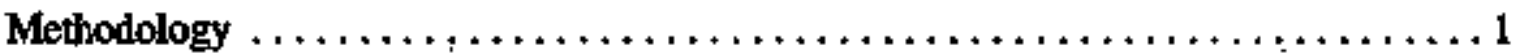

Summary of Aggregate Results $\ldots \ldots \ldots \ldots \ldots \ldots \ldots \ldots \ldots \ldots \ldots \ldots \ldots$

1. Intermational Considerations $\ldots \ldots \ldots \ldots \ldots, \ldots \ldots \ldots \ldots \ldots \ldots \ldots \ldots \ldots \ldots, \ldots, \ldots$

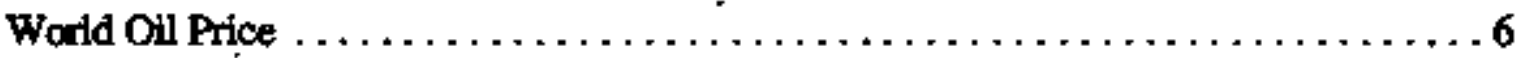

Worldwide Supply and Demand $\ldots \ldots \ldots \ldots \ldots \ldots \ldots \ldots \ldots \ldots \ldots \ldots$

North American Free Trade Agreement $\ldots \ldots \ldots \ldots \ldots \ldots \ldots \ldots \ldots \ldots \ldots 11$

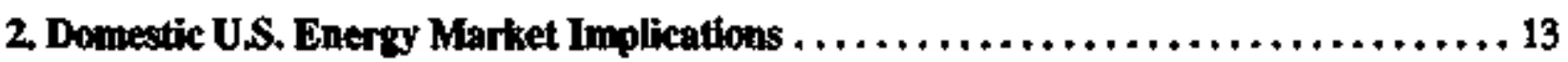

Dynamics of Changes in Production and Consumption $\ldots \ldots \ldots \ldots \ldots \ldots \ldots \ldots 13$

The Decline in Net Oil Imports $\ldots \ldots \ldots \ldots \ldots \ldots \ldots \ldots \ldots \ldots \ldots \ldots \ldots$

3. Macreecononite Implications $\ldots \ldots \ldots \ldots \ldots \ldots \ldots \ldots \ldots \ldots \ldots \ldots \ldots \ldots \ldots, 19$

World Oil Price Sensitivities $\ldots \ldots \ldots, \ldots, \ldots \ldots \ldots, \ldots \ldots \ldots \ldots, 19$

Ir pacts on the Aggregate Economy $\ldots \ldots \ldots \ldots \ldots \ldots \ldots \ldots \ldots \ldots \ldots$

Impacts on Sectors of the Economy $\ldots \ldots \ldots \ldots \ldots \ldots \ldots \ldots \ldots \ldots, 22$

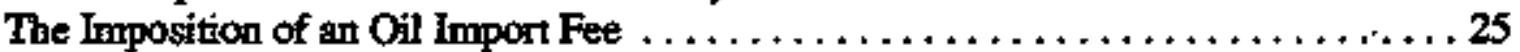

How Will the U.S. Government Use the Collected Revenues? . . . . . . . 25

How Are the Impacts Different than from Higher World Oil Prices? . . . . . . 32

How Do Flexible Fixchange Rates and Monetary Policy Affect the Results? . . 35

Appenidix:

Letter of Request for Study from the General Accounting Ofice 38

The Imapacts on US. Eneray Mankets and the Economy of Reduding Oif Imports Eneray Infermation Administration, September 1996 


\title{
The Impacts on U.S. Energy Markets and the Economy of Reducing Oil Imports
}

\begin{abstract}
The General Accounting Office (GAO) has responded to a request from Representative John Kasich by requesting that the Energy Information Administration (EIA) use the National Energy Modeling System (NEMS) to estimate the cost to the U.S. economy of reducing oil imports. The aralysis summarized by this paper focuses on two approaches toward a target reduction in oil imports: (1) a set of cases with altemative world crude oil price trajectories and (2) two cases which investigates the use of an oil import fee.

\section{Methodology}

What is the cost of redacing oil imports relative to the existing levels found in the Reference Case of the 1996 Annual Energy Ortlook? The answer to this question depends on the mechanism for achieving the reduction. The first approach focuses on a set of world crude oil price increases. Higher prices for energy reduce energy imports but cost the economy in terns of lost output and purchasing power. Four price trajectories were developed to investigate this issue. They exceed the EIA 1996 Annual Enorgy Outlonk (AEO96) Reference Case price path by $\$ 5$ per barrel, $\$ 10$ per barrel, $\$ 15$ per barrel, and $\$ 20$ per barrel by 2005 . The ratio of each new 2005 world oil price and the 2005 AEO96 Reference Case price is then maintained from 2006 through 2015 for the altemative cases (Figure 1A). These four cases will be referred to throughout the document as $+\$ 5,+\$ 10,+\$ 15$, and $+\$ 20$ to indicate that in all instances they are incremental to the AEO96 Reference Case world oil price path.
\end{abstract}

The second approach posits an oil import fee which achieves oil import reductions in 2005 equivalent to those projected when oil prices are $\$ 20$ above the Reference Case level Here, two basic cptions are investigated: (1) using the collected revenues to reduce the Federal deficit and (2) recycling collected funds to maintain the Federal deficit at the same level as in the Reference Case. The return of revenpes is accomplished through a reduction in the payroll tax rate.

\section{Sumuary of the Asgregate Results}

Four integrated model nuns were implemented to relate oil import reduction projections to alternative world oil price increases (Figure 1B). With higher world oil prices, domestic production increases and demand is constrained. By 2005 , the $+\$ 5$ case reduces oil imports by $1.2 \mathrm{mmbd}$, while the $+\$ 20$ case backs ont $3.2 \mathrm{mmbd}$ (Figure 1C). By 2015 , the $+\$ 5$ case results in a reduction of $1.8 \mathrm{mmbd}$, while the $+\$ 20$ case results in a reciuction of $4.7 \mathrm{mmbd}$. The results 

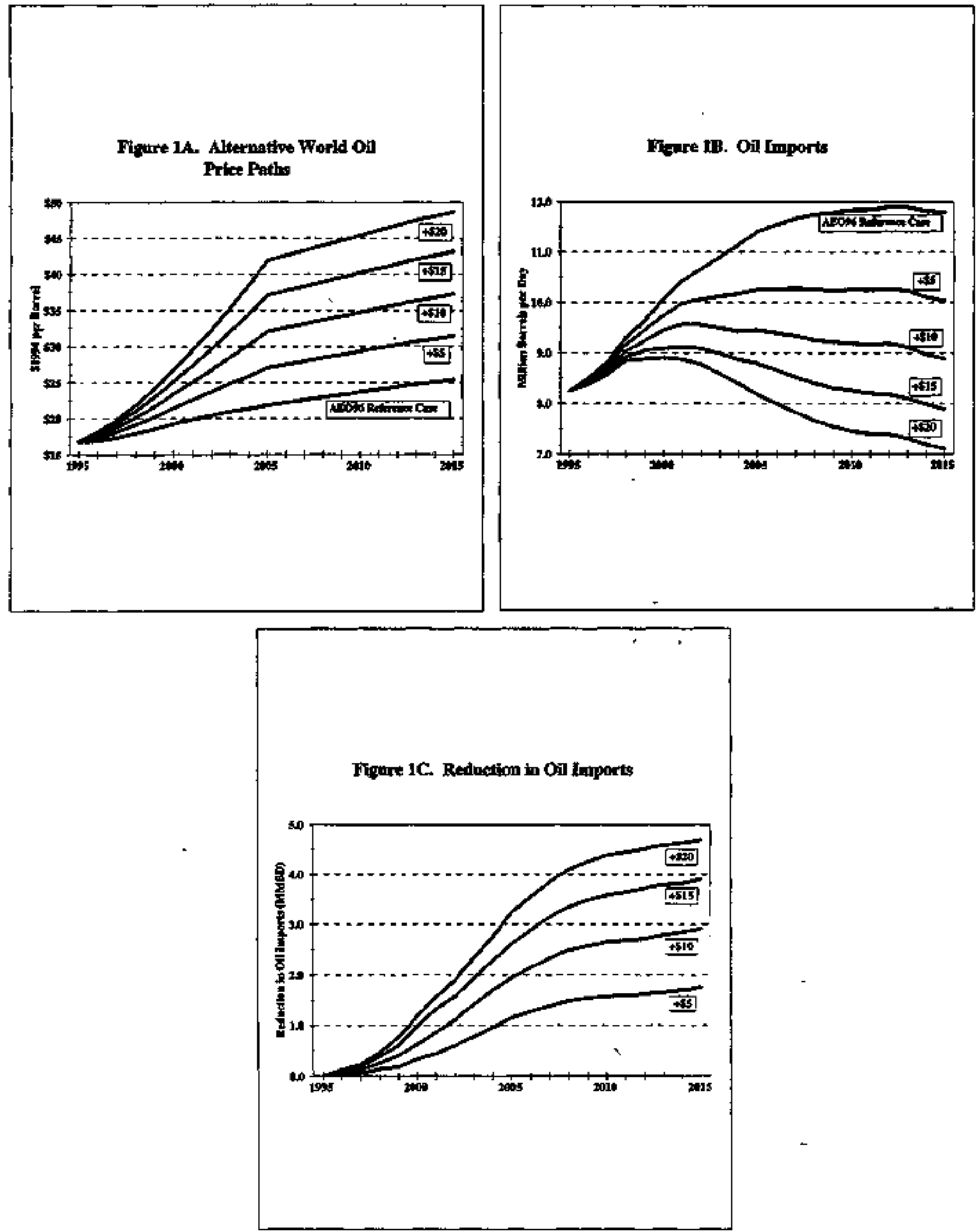

The Inpacts on U.S. Eoergy Markets and the Economy of Redheine Oil Imports Energy Information Administration, September 1996 
Figure 1D. Change in World Oil Price

Relative to Import Reduction, in 2005

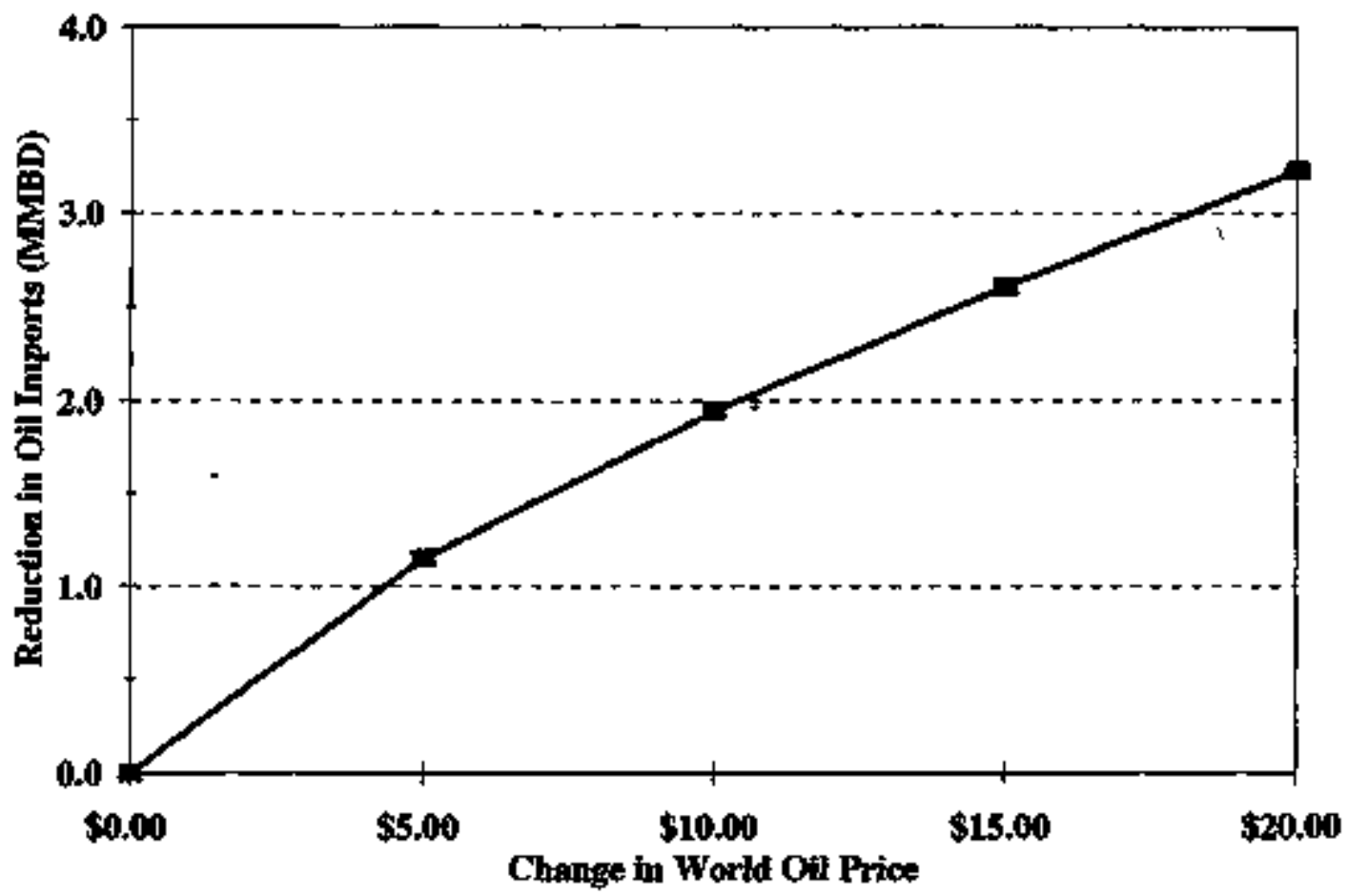

Figure 1E. Loss in GDP and

Import Reduction In 2005

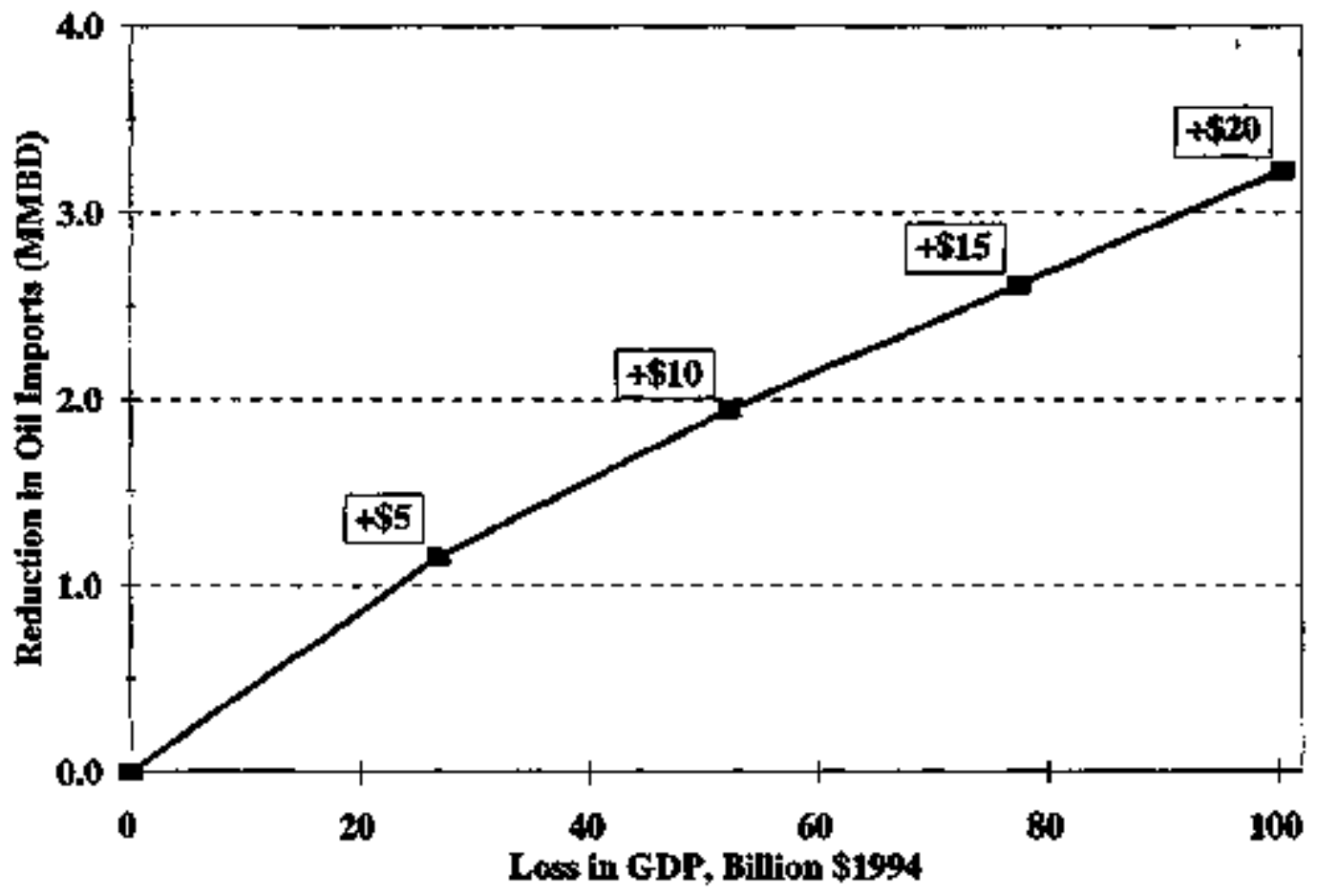

The Impacts on U.S. Energy Markets and the Feonomy of Redacing Oil Inports Energy Information Admimistration, September 1996 
indicate that each successive reduction of one million barrels per day of oil imports can only be achieved at progressively higher costs. The first ten dollars of price increase yields a reduction in oil imports of 2 mmbd by 2005 , while the next $\$ 10$ yields only an additional 1.2 mmild (Figure 1D). Economic impacts, as reflected by changes in GDP, wirror the changes in the world oil price (Figure 1E).

The Import Fee Case experiment yields energy market effects which are faitly sinilar to the $+\$ 20$ case. However, the macroecononic impacts are more complex in part because the fee generates substantial revenues. How the funds are used makes a large difference. In addition, the fee case has effects on intemational trade patterns and restructares U.S. imponts and exports. As shown in Figure 2, when the fee revenues are used to reduce the Federal deficit, the economy is atversely affected through 2005, but begins to retum to the Reference Case throughout 2015. In the early years, the economy is adversely affected by higher exergy prices; in the latter years, interest rates decline in response to the lower Federal deficit, and an investment-led rebound cocurs.

When the Federal deficit is targeted to remain at the Reference Case level, the economy is essentially kept at or slightly above the Reference Case through 2005, but declintes thereafter. -Here, the early results stem from supporting consumption expenditures by passing collected funds back to consmmers. While this ameliorates the near-term effects, investment suffers and the economy begins to rapidly decline relative to the Reference Case. Also in the deficit reduction case, the impact on GDP measured over the entire forecast period is approximately two-thirds of the impact of the $+\$ 20$ case. Here, the fee adversely affects the U.S. export prices relative to import prices, whereas in the $+\$ 20$ case, all nations experience higher energy prices. 


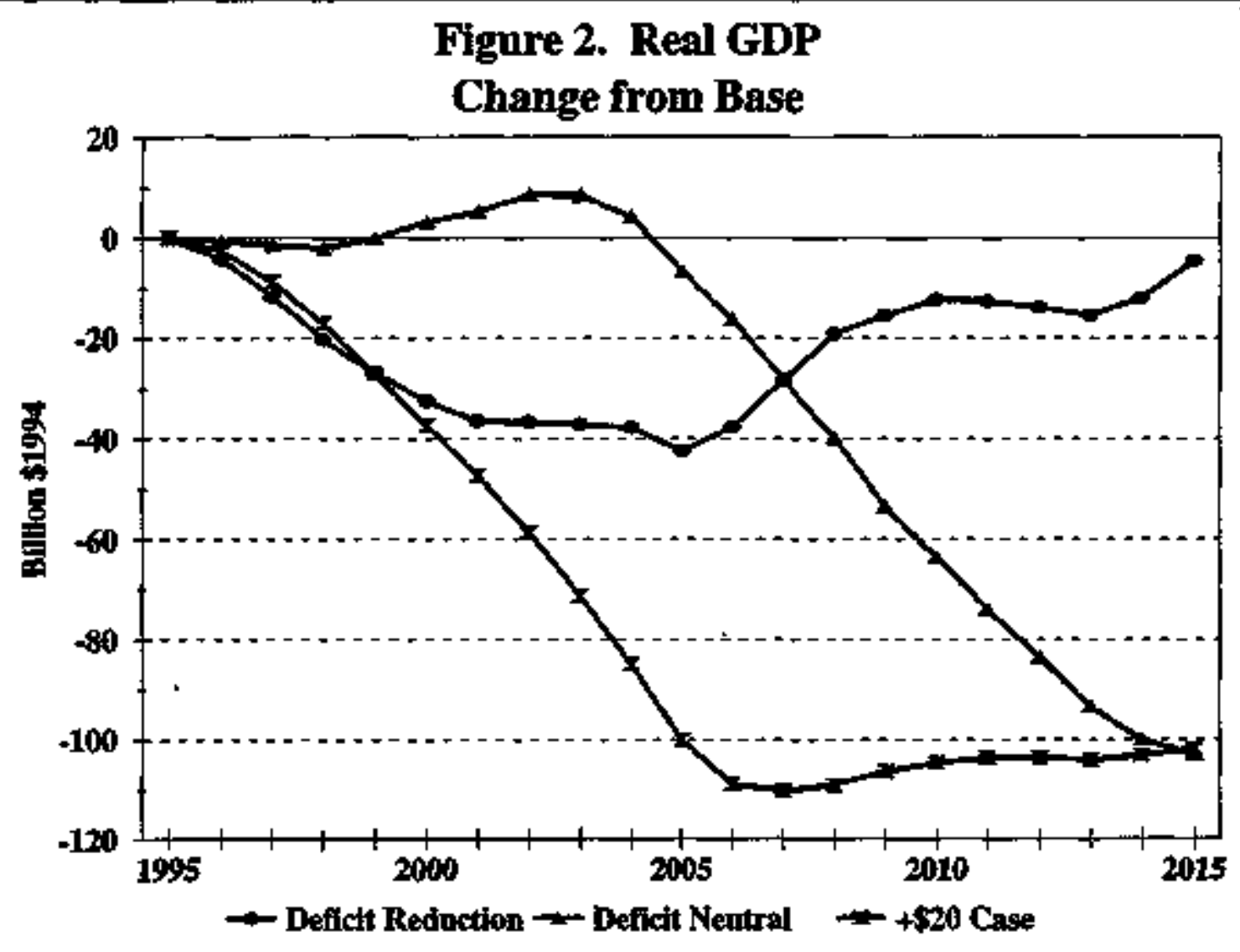

The Impacts on U.S. Energy Markets and the Economy of Reducing OAl Imports Enerty Infornation Administration, September $19 \% 6$ 


\section{International Considerations}

\section{World Oil Price}

Four oil price cases were defined starting with the Annual Energy-Ongtlook 1996 (AEO96) Reference Case as the point of departure. Beginning with the year 1996, the world oil price was assumed to steadily increase out to the year 2005 achieving price kvels that were $\$ 5, \$ 10, \$ 15$, and $\$ 20$, respectively, over the $A E O 96$ Reference Case world oil price $(\$ 21.86)$. The ratio of each new 2005 world oil price and the 2005 AEO96 Reference Case price is then maintained

- from 2006 througin 2015 for the alternative cases.

For the purpose of assessing the irupacts of an oil import foe, the $+\$ 20$ Case was chosen as the point of comparison. An Import Fee Case was defined that used the year-by-year net import levels from the $+\$ 20$ Case as targets. In order to achieve these targets, a fee on all petroleum imported into the United States is imposed over and above the world oil price. The only exceptions to the import fee are the crude oils and refined products imported from our partners (Canada and Mexico) in the North American Free Trade Agreement (NAFTA).

Figure 3A shows the three world oil price paths associated with the AEO96 Reference Case, the $+\$ 20$ Case, and the Import Fee Case. By definition, the $+\$ 20$ Case achieves the $\$ 20$ difference with the $A E O 96$ Reference Case by the year 2005. The difference expands to over $\$ 23$ by the end of the forecast period. In the Import Fee Case, the decline in U.S. consumption and increase in U.S. production brought about by the imposition of the oil import fee results in levels of production from Organization of Petroleum Exporting Countries (OPEC) suppliers that are below those of the AEO96 Reference Case. Therefore, with a diminished call on OPEC producers, the world oil price path in the Ixuport Fee Case is expected to be slightly below that of the AEO96 Reference Case. However, this diminished call on OPEC producers is somewhat tempered by the response of foreign consumers and producers to lower world oil prices.

Figure 3B focuses on the price implications of the Import Fee Case. The world oil price is that price realized by all oil consumers outside the United States. Due to the imposition of an oil import fee that eventually reduces U.S. net imports by over 3 million barrels per day, dornestic consumers experience oil prices that exceed the world oil price by more than $\$ 20$ per barrel ( $\$ 22.36$ in the year 2005 and $\$ 24.50$ in the year 2015). For any given year during the forocast period, the vertical distance in Figure 3B between the world oil price and the U.S. oil price is the oil import fee.

'Throughout this paper, values for prices and economisc concepis such as GDP and sectoral output are expressed in constant 1994 dollins.

The Impacts on U.S. Fnergy Martets and the Economy of Redaking Oly Imports Enaroy Informotion Admintstration, September 1996 

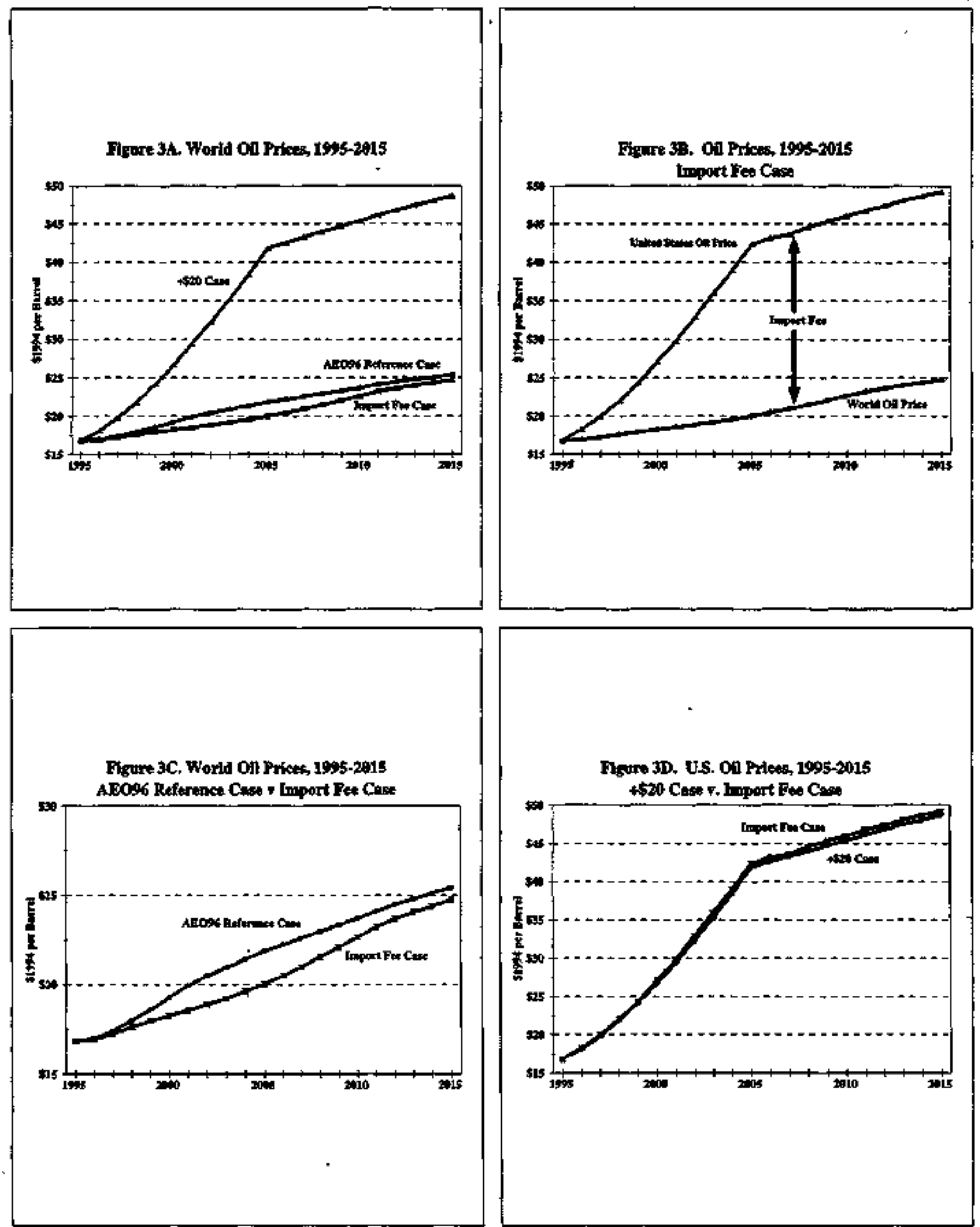

The Impacts on U.S. Eneryy Markets and the Economy of Reducing Oil Imports Butrgy Imformation Administrotion, September 1996 
Figure $3 C$ compares the world oil price paths associated with the $A E O 96$ Reference Case and the Import Fee Case. As the oil import fee rapidly escalates over the decade from 1995 to 2005 , the U.S. is able to reduce their net imports of petroleum by almost 3.25 million barrels per day. Such significant import reduction directly translates into a reduced call on OPEC producers resulting in world oil prices in the Import Fee Case that are lower than those in the AEO96 Reference Case. These two price paths tend to slightly diverge over the $1995-2005$ period as the increasing oil import fee diminishes the call on OPEC producers. After the year 2005, the gap between the two price paths begins to narrow as the oil import fee stabilizes and worldwide oil demand (outside the U.S.) responds to the lower prices.

Figme 3D compares the oil price paths experienced by U.S. consumers and producers in the +\$20 Case and the Import Fee Case. Because the Import Fee Case targets the petroleum inport levels associated with the $+\$ 20$ Case, these two price paths tum ont to be virtually identical, as Figure 3D suggests. However, the Inpont Fee Case price path is consistently a little higher than the $+\$ 20$ Case. The reason for the slight difference (which never exceeds $\$ 0.60$ per berrel in any one year) is NAFTA. In the $+\$ 20$ Case, some of the imports from our NAFTA partners were part of the overall reduction in net U.S. imports. However, in the Import Fee Case, the U.S. will always import whatever petroleum is available from Canada and Mexico in order to avoid the oil import fee. Therefore, more expensive imports from non-NAFTA sources will have to be reduced in order to meet the target levels (from the $+\$ 20$ Case) in the Import Fee Case. This results in a slightly greater U.S. oil price in the Import Fee Case than in the $+\$ 20$ Case.

\section{Worldwide Supply and Demand}

In the $+\$ 20$ Case, all consumers and producers worldwide experience the tripling of oil prices over the forecast period. In the Import Fee Case, only U.S. consumers and producers experience this tripling. Figure 4 shows OPEC production over the forecast period for the AEO96 Reference Case, the $+\$ 20$ Case, and the Impont Fee Case. OPEC production exceeds 52 million barrels per day by 2015 in the AEO96 Reference Case; and although this level of production falls off by more than 22 percent (to about 40.5 million barrels per day) by the end of the forecast period in the $+\$ 20$ Case, the tripling of the world oil price results in an almost doubling of OPEC revenues over those realized in the AEO96 Reference Case. In the Import Fee Case, the call on OPEC producers is reduced by more than 3 million barnels per day below the AEO96 Reference Case due to the U.S. production and consumption response to an oil impont fee, bat the lower prices enjoyed by consumers outside the U.S. tend to coumterbalance the U.S. response resulting in a net reduction in OPEC production that averages between 2 and 2.5 million barrels per day after the year 2005 .

Figure 5A presents U.S. and OPEC oil production for the years 2005 and 2015 for the $A E O 96$ Reference Case, the $+\$ 20$ Case, and the Import Fee Case. With the tripling of oil prices, the U.S. shows a robust production response that is almost 25 percent higher than the $A E O 96$ Reference Case in the year 2005 and more than 34 percent higher in the year 2015 . In the $+\$ 20$

The Impacts on U.S. Fnerwy Markets and the Economy of Reducing Oil Imports Eneros Infornation Admintistration, Septeraber 1996 
Figure 4. OPEC Production, 1995-2015

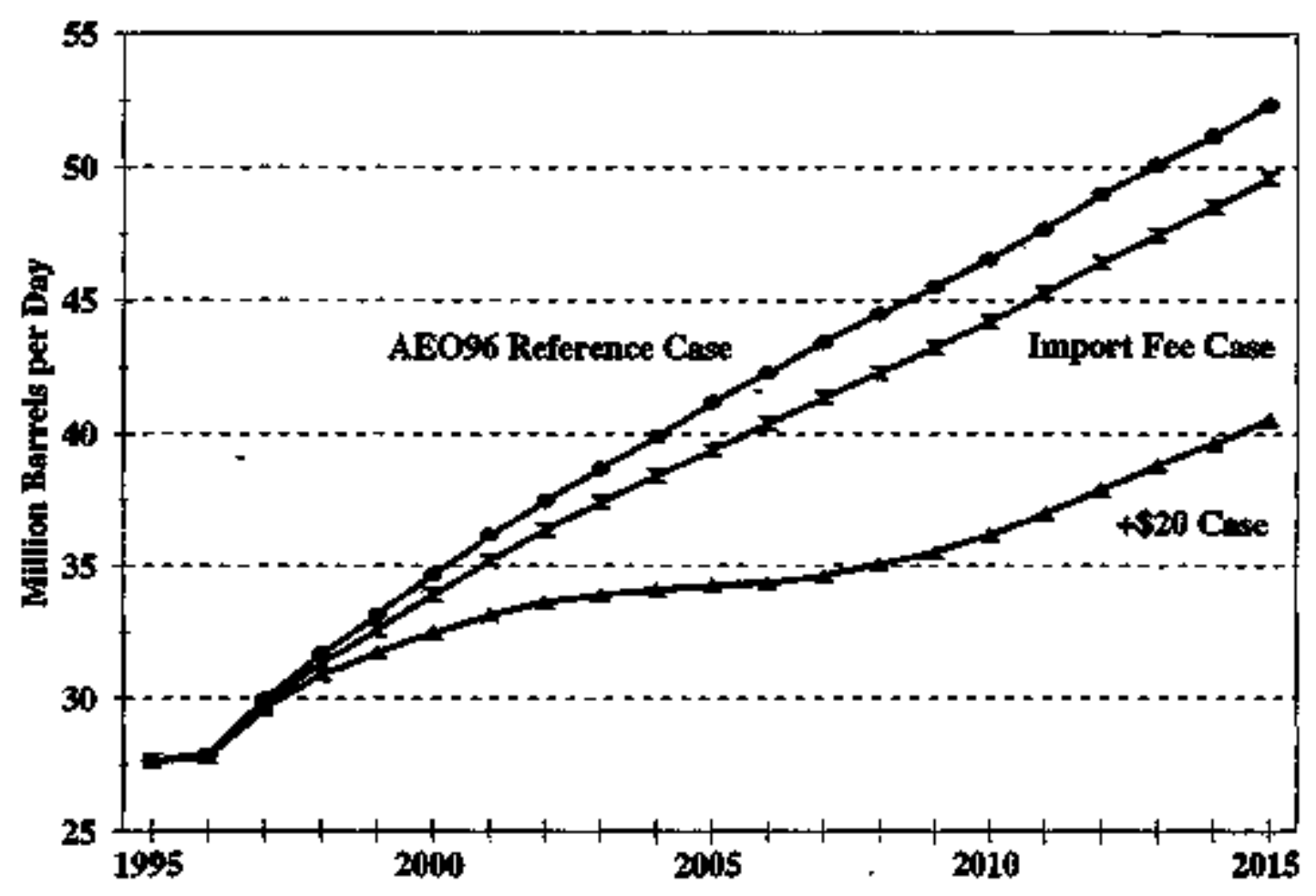


Figure 5A. U.S. \& OPEC Oll Production

Years 2005 and 2015

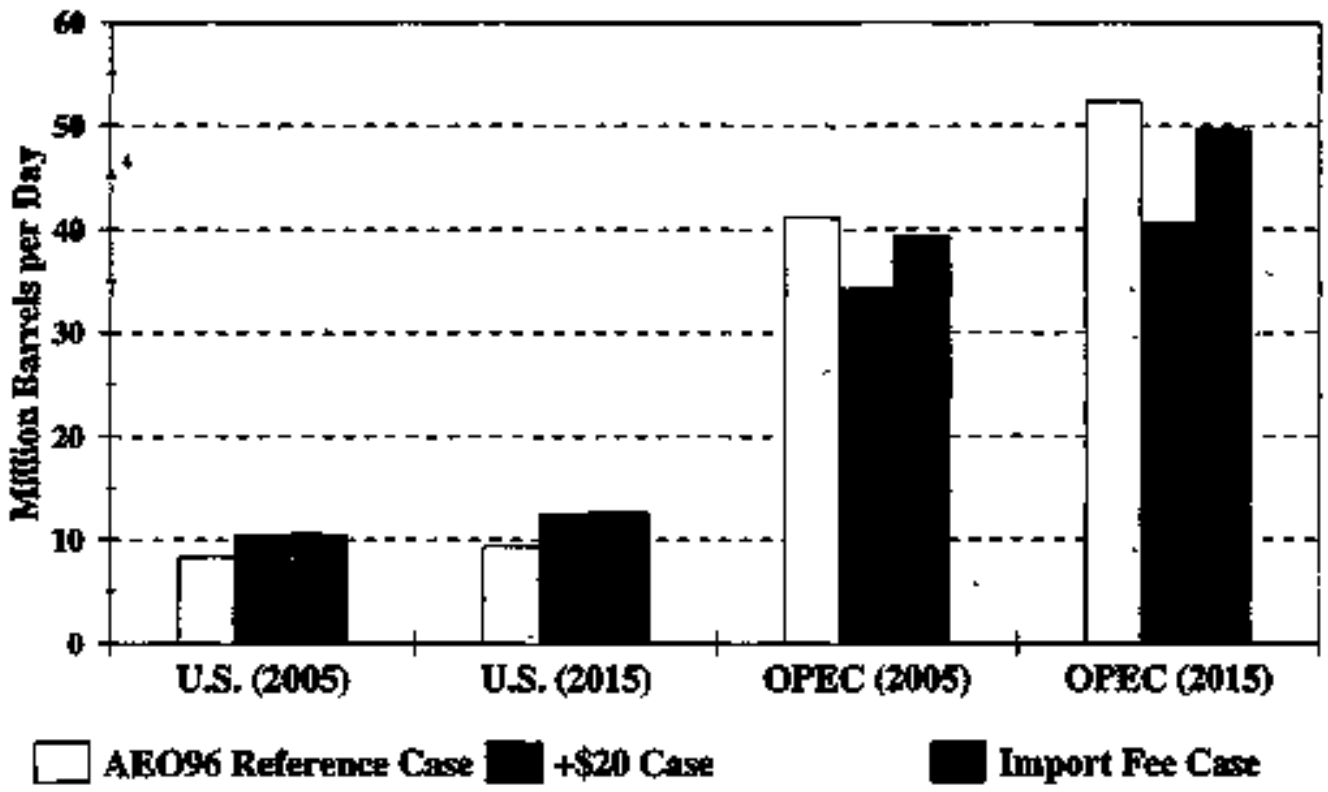

Figure 5B. World Oil Consumption

Years 2005 and 2015

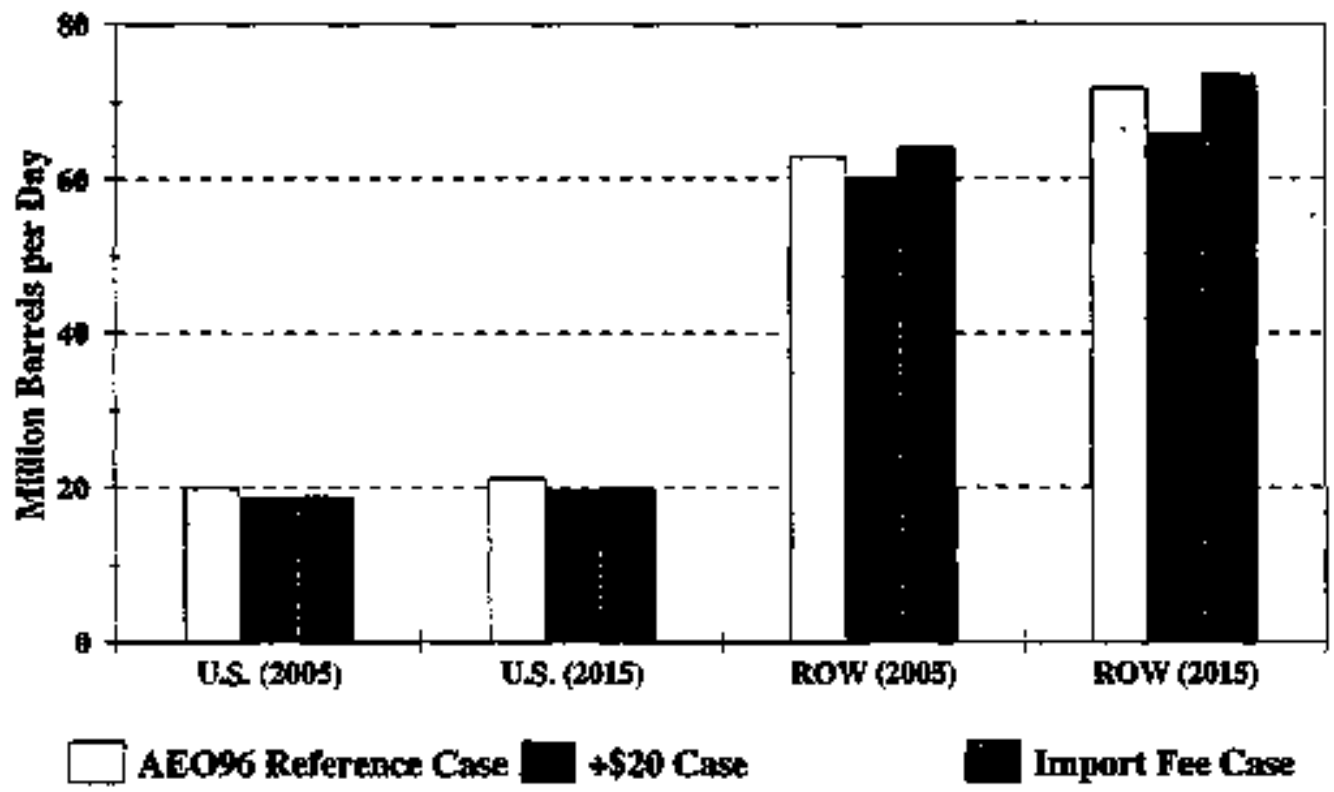

ROW = Rest of World

The Impacts on U.S. Energy Markets and the Economy of Redineing Oil Imports Eneray If formation Administration, Septenlyer 1996 
Case, the growth in OPEC production capacity is expected to be a modest 2 percent per year over the forceast period compared to the moderate 3 pencent growth reflected in the AEO96 Reference Case.

Figure 5B shows world oil consumption for the years 20,05 and 2015 for the AEO $\%$ Reference Case, the $+\$ 20$ Case, and the Import Fee Case. With the tripling of oil prices, the U.S. shows only a modest consumption response that is about 6 percent lower than the AEO96 Reference Case in the year 2005 and not quite 7.5 percent lower in the year 2015. The comesponding nonU.S. consumption response is only slightly more robust (gveraging a little more than an 8 percent consumption decline by the year 2015) in the $+\$ 20$ Case due to the greater demand and income response of non-U.S. consumers to higher prices. While the U.S. consumption response in the Irmport Fee Case is similar to that of the $+\$ 20$ Case, the non-U.S. consumption response is about 1.8 percent higher than the Reference Case in the year 2005 and almost 2.3 percent higher in the year 2015 due to the lower world oil price path induced by the U.S. import fee.

\section{North Americhn Free Trade Agreement}

For the Import Fee Case, it was assumed that perroleum (both crude oils and refined protucts) imported from our NAFTA partners (Canadi and Mexico) was not subject to the oil import fee. It was also assumed that the volumes of petroleum available for impont from on NAFTA partners would be limited to the volumes that were available on the import supply curves in the Reference Case. These curves were considered reasonable for use in the Import Fee Case becanse they were purposefully generated to give the U.S. considerable import flexibility. Figur 6 shows the volumes that were assumed available. Without exception, these volumes were imported to their limit in the Import Fee Case. In the $+\$ 20$ Case as well as the Reference Case, import volumes from our NAFTA partmers were below the upper limits for all years of the forecast period. 


\section{Figure 6. Oil Available for Import from Canada and Mexico}

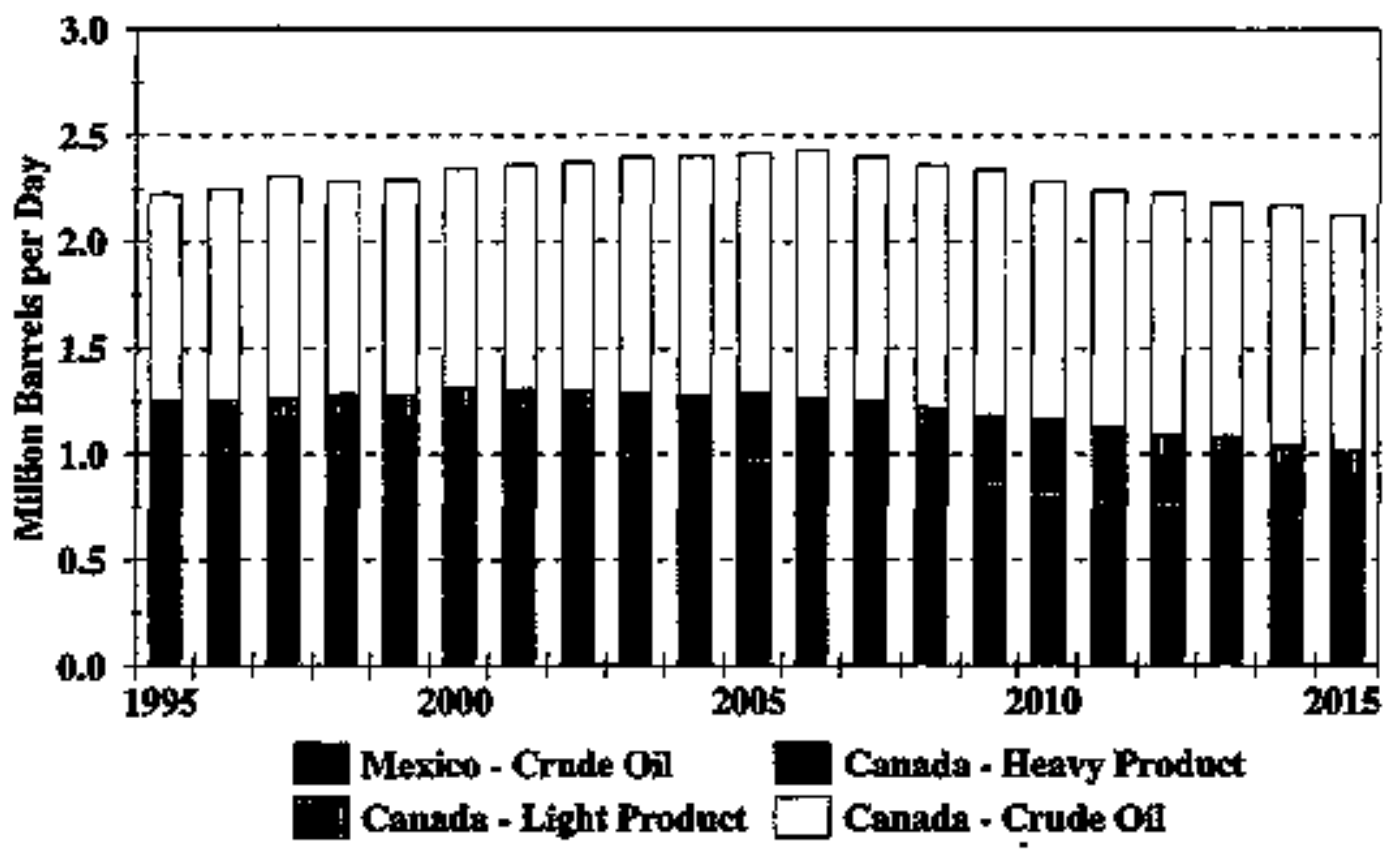




\section{Domestic U.S. Eaerzy Market Implicotions}

\section{Dynamics of Changes in Production and Consumption}

Increased crude oil prices have a predictable effect on the U.S. energy sector -- domestic oil production is expected to increase, while transportation fuel demand declines. Increased oil prices have indirect effects on natural gas and coal production and other aspects of the energy system, but these effects are modest relative to direct impacts on oil production and transportation demand for oil.

Figures 7A and 7B display the relative effects of changes in domestic energy production and consumption on reducing net petrolenm imports for four time periods: $2000,2005,2010$ and 2015. Throughout the forecast period, increasing energy production accounts for between 70 to 75 percent of the oil import reduction, while declining consumption accounts for between 20 and 30 percent.

When the focus is on domestic prodaction and consurmption of petroleam instead of total energy, a different pichure emerges (Figures $7 \mathrm{C}$ and $7 \mathrm{D}$ ). The reduction in oil imports is evenly split between increased domestic petroleum production and reduced petroleum consumption in the year 2000. Over time, increased domestic petroleum production accounts for more of the decrease in oil imports, stabilizing at approximately 65 percent in 2010.

Production. Higher oil prices make previously unprofitable oil drilling projects more attractive to exploration and production companies and their investors. Drilling increases in smaller fields, more remote locations, or unconventional oil deposits as higher oil prices reduce the risk of previously marginal projects. More drilling leads to the discovery of more oil resources, especially with today's more acctrate exploration and development techniqpes, such as slim hole drilling and three- and four-dimensional seismic studies. More drilling also converts more resources into producible reserves. Higher prices give producers an incentive to pump more oil out of the ground as quickly as possible. High oil prices may also make it profiable to produce oil from exotic sources, such as those investigated in the wake of the 1970 's oil crises. These "backstop" technologies include extracting petroleum from oil shale and making synthetic crude oil from coal. However, such responses are not reported, as the time frame for significant development extends beyond the time horizon projected here.

With higher energy prices, domestic energy production becomes more profitable and is stimulated. Since this stady focuses on the "value of imports" to the U.S. oconomy, the focus is on changes in the U.S. oil market and, to a lesser extent, on the gas market (Figure 8A). U.S. oil production increases in the $+\$ 20$ case over the 1995 to 2015 forecast period, while it largely declines in the AEO96 Reference Case over the same period. This is because of the increased profitability of domestic oil production brought on by higher world oil prices. U.S. oil

The Impacts on US. Energy Martets and the Economy of Reducing On Imports Eneroy Informatioun Administratlon, Septeimber 1996 

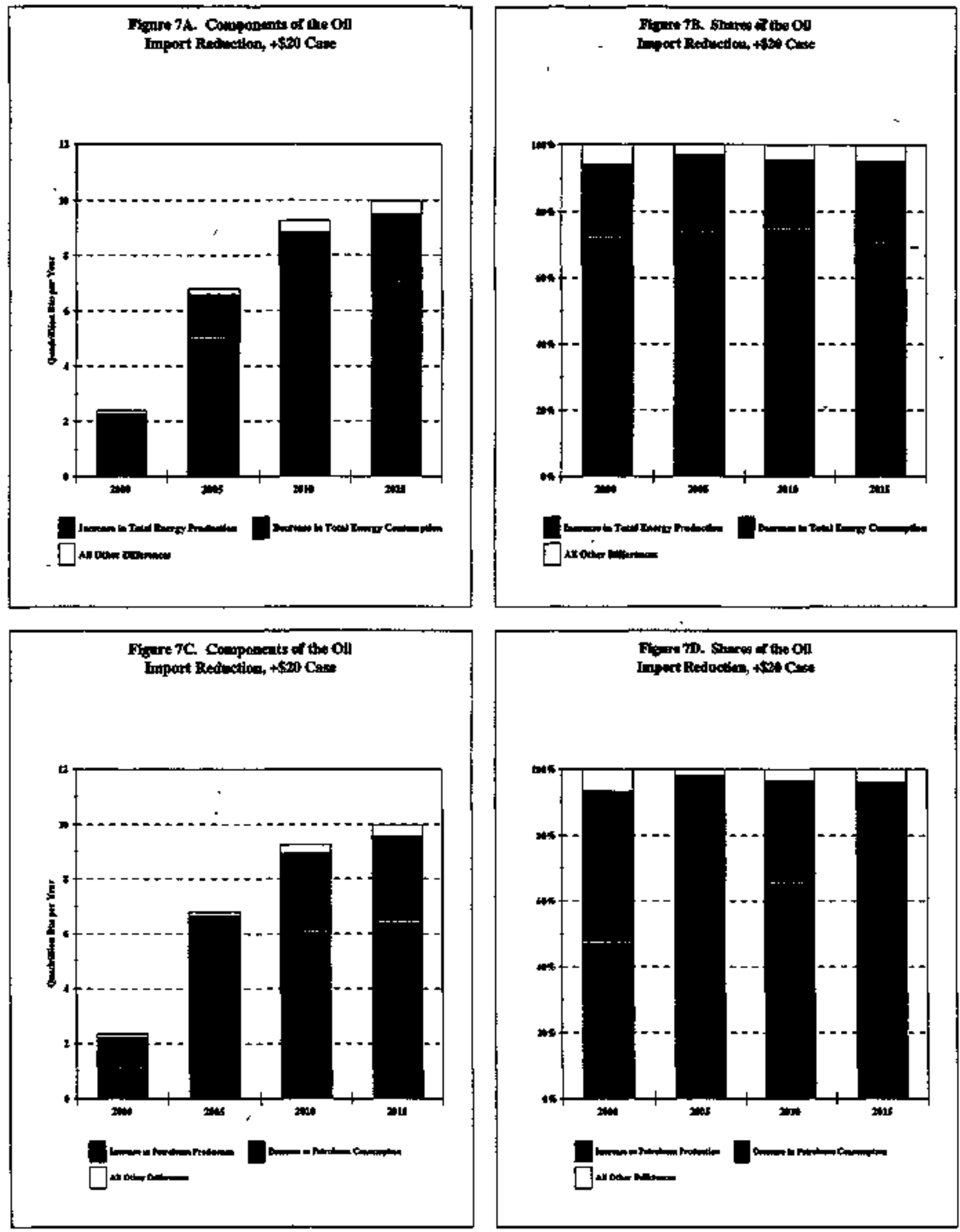

The Impacts on U.S. Energy Markets and the Economy of Reducing Oil Imports Energy Information Administration, September 1996 

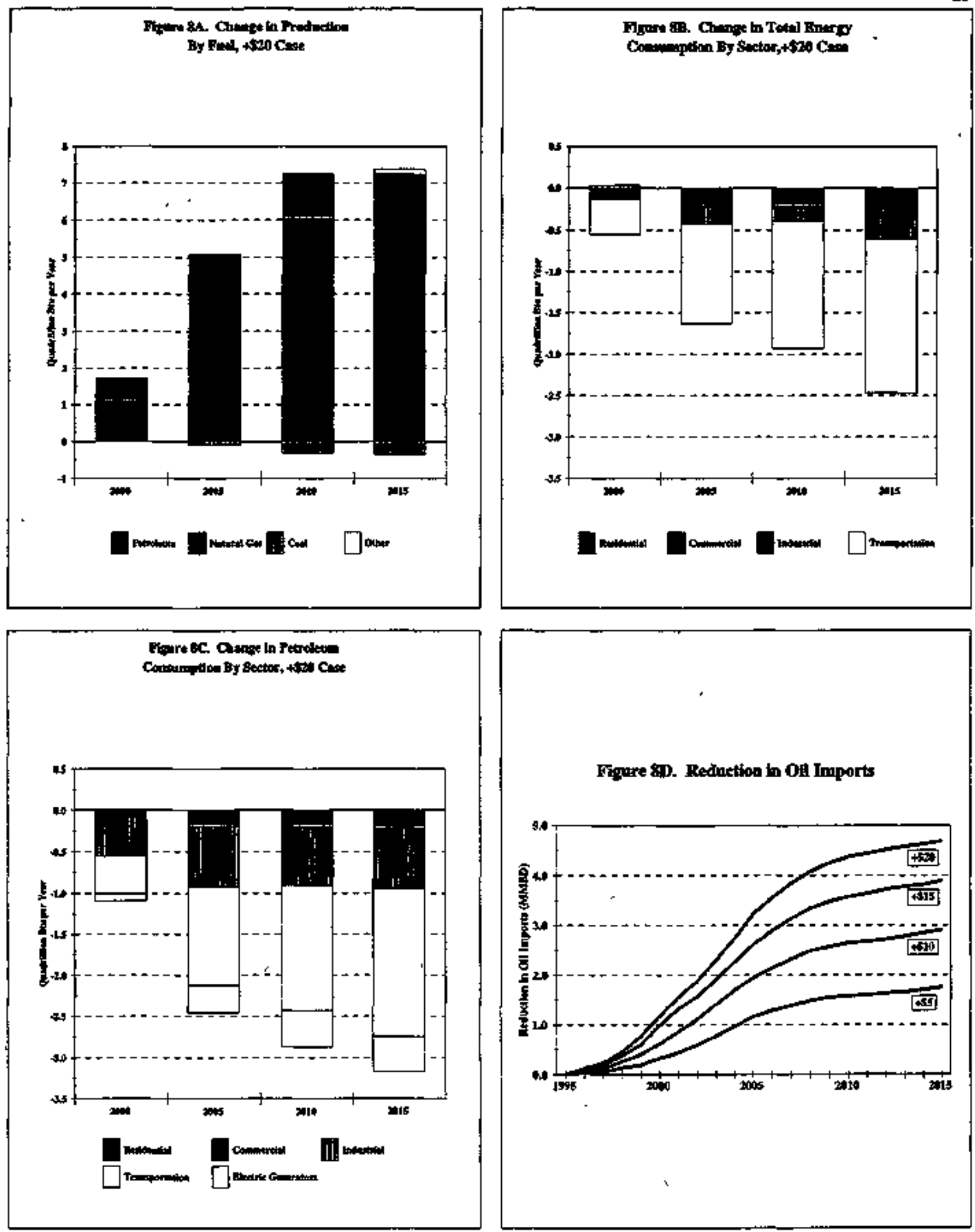

The Impacts on U.S. Energy Markets and the Economy of Redueing Oil Inparts

Enersy Information Adninistration, September 1996 
production increases in the $+\$ 20$ case at a 1.5 percent annual rate, compared to a 0.6 percent annual decrease in the $A E O 96$ Reference Case. In both cases the production pattem closely follows the reserve position of the industry. In the $+\$ 20$ case reserves bottom out in 1999; in the Reference Case they bottom out in 2004. The sharp rise in the oil price is the major reason for the tifference in production between the AEO and the $+\$ 20$ case. Higher reserves reflect increased drilling induced by the higher oil prices. The number of oil wells drilled in 2015 is 63 percent higher in the $+\$ 20$ case than in the AEO96 Reference Case. In 2005 oil production in the $+\$ 20$ case is $1.9 \mathrm{Mmbd}$ or 37 percent higher than in $A E O 96$, and in 2015 it is 3.0 mmbd or 52 percent higher.

In the early years of the forecast, conventional onshore lower 48 crude oil production accounts for more than half of the higher oil production in the $+\$ 20$ case, reflecting the dominance of corventional onshore reserves. The importance of conventional onshore production diminishes laver in the forecast as enhanced oil recovery and offshore production grow and onshore supply experiences some depletion effects. Alaska production stays at a higher level in the $+\$ 20$ case than in the Reference Case throughout the forecast period, but does not exceed 1995 levels by 2015.

Natural gas production is 4 percent higher in 2005 and 3 percent higher in 2015 in the $+\$ 20$ case than in the Reference Case. Driven primarily by the oil production, the cumulative associated dissolved natural gas production from 1994 through 2015 is 18 percent higher in the $+\$ 20$ case than in the Reference Case; whereas the cumulative nonassocinted production is only 1.4 percent higher.

Renewable energy production (on a Btu basis) is 2 percent higher in 2015 in the $+\$ 20$ case than in the Reference Case. This represents a limited market potential for renewables and natural gas prices remaining competitive through 2015 (at $\$ 3.24 / \mathrm{mct}$ ).

The discussion above focused on the $+\$ 20$ case. In going between the price cases, there is a slight non-linearity in the relationship between the price change and the level of oil import reduction. Esch successive rectuction of one million barrels per day of oil imports can only be achieved at progressively higher costs. Cude oil reserve additions come primarily from upward revisions and adjustments to the reserves of older fields, not from new discoveries. The increase in the world oil price between cases stimulates more drilling and extends development efforts to more costly resources. Hence, the first ten dollars of price increase yields a reduction in oil imports of 2 mmbd by 2005 , while the next $\$ 10$ yields only an additional $1.2 \mathrm{mmbd}$.

Consumption. In the $A E O 96$ forecast, end-use consumption of oil remains concentrated in providing transportation services and this sector is responsible for most of the reduction in total energy demand in the cases addressed in this paper (Figure 8B). Transport vehicles (with the exception of electric powered trains) must carry their energy supply with them. As a result, unlike fuels used in other applications, the energy content per unit volume and weight are critical

The Impgcts on US. Energy Martets and the Econongy of Reducing OAl Imports Enaray Informatien Administration, September 1996. 
elements in the choice of transpontation fuels. Given curnently demonstrated technologies, petrolepm products are not likely to be replaced as the transportation sector fuel of choice uniess other factors (e.g. legislation mandating changes in fuel choice decisions, public concem over global waming) dominate future fuel choice decisions. Energy prices still affect transportation energy consumption, however, this is almost completely the result of improved efficiency in petroleum-based technologies, not switching to altemative transportation fuels. Based on the higher gasoline price path assumed in the $+\$ 20$ Case consumers purchase vehicles in 2015 that are more than 15 percent more fuel efficient than in the Reference Case. Gasoline prices in 2005 and 2015 are more than 30 percent higher in the $+\$ 20$ Case than in the Reference Case. Personal travel in vehicles declines by less than 2 percentage points in each of these years (compared to the Reference Case) reflecting the historic relative insensitivity of personal travel to gasoline prices and the fict that rising vehicle efficiencies dampen the actual increase in the fuel cost of driving a mile facing consumers.

Within the transportation sector the technical potential and time frame for improving the energy efficiency of the stock of equipment varies significantly by transportation mode. Marine and rail freight transport, for example, account for practically notse of the reduction in transportation oil consumption in the $+\$ 20$ case even though combined they consume nearly 8 percent of transportation energy use. The slow rate of capital stock turnover in these modes serves as a natural brake limiting average efficiency improvements within the time horizon being considered.

Although the mansportation sector is responsible for most of the decrease in total energy consumption, the industrial and electric generation sectors also decrease their petroleum inputs considerably (Figure 8C). These two sectors bsve greater potential for fuel switching, which is why the industrial sector's total energy demand falls only 0.2 quatrillion Bta per year, when petroleum consumption is 0.7 quadrillion Btu lower. The inputs to electric generation, as well as the asscciated transmission and distribation losses, are allocated to the four end-use sectors in Figure 8B.

\section{The Decline in Net Oil Imports}

The $+\$ 20$ Case. Net oil imports rise during most of the forecast in the AEO96 Reference Case, from 8.3 million barrels per day in 1995 to a peak of 12.9 mitlion batrels per day in 2013. Net imports fall during the final two years of the forecast, as increases in domestic oil production begin to keep pace with increases in demand fot petroleam products. Net oil imports follow a markedly different path in the $+\$ 20$ case. OiI imports peak in 2000 at 8.9 million barrels per day and decline for the remainder of the forecast to 7.1 million barrels per day in 2015 . Imports begin to decline much more quickly in the $+\$ 20$ case, because higher oil prices encourage increasing production beginning in 2000, instead of 6 years later as in the AEO96 Reference Case. Net petroleum imports in 2005 are 3.2 million barrels per day lower in the $+\$ 20$ case than in the AEO96 Reference Case; in 2015 they are 4.7 million barrels per day lower (Figure 8D).

The Impacts on U.S. Energy Markets and the Ecoenmy of Reducing Oil Imports Energy Information Administration, September 1996 
The Oil Impart Fee. By design, the $+\$ 20$ case and the Import Fee Case lower petroleum imports by the same amount. The primary difference between the two cases is in the mix of imports between crade oil and petroleum products. In the tariff case crude oil imports decline and petroleum prothct imports increase, even as total petroleam imponts remain abont the same. Product imports increase in the tariff case because inexpensive imports become available from Canadi and Mexico under the North American Free Trade Agreement. By 2015 net crude oil imports are 440,000 barrels per day lower in the tariff case, and net produet imports are 490,000 barrels per day higher, than in the $+\$ 20$-plus case. 


\section{Macroeconomic Implications}

\section{World Oti Price Sensitivities}

\section{Inpacts on the Aggregate Economy}

Changes in Potentisl Output and Adjustment Costs. Higher energy costs will reduce the use of energy by shifting production towand less energy-intensive sectors, by replacing energy with labor and capital in specific production processes, and by encouraging energy conservation. Although reflecting a more efficient use of higher-cost entergy, this gradual reduction in energy use will tend to lower the productivity of other factors currently being used in the production process. Moreover, if higher energy prices raise intecest rates or the price of capital goods relative to the wage rate, capital formation and the capital-labor ratio will be reduced over time. These factors result in a loss in the potential output of the economy.

While reducing potential output, higher energy prices also will cause short-run adjustment effects. Higher energy prices will raise production costs and bower aggregate spending. Immediately after energy prices increase, substitution away from energy is limited and the prices of other inputs do not fall. This raises the short-rin production costs per unit of output for firms. Moreover, spillover effects on wages and other variable costs will further escalate production costs throughout the economy. This will place upward pressure on the nominal prices of intermediate goods and final goods and services.

A rising aggregate price level will reduce real spending on U.S. goods and services in several ways. In a direct response to higher energy prices, consumers cut back on the amount of energy consumed, but their nominal expenditures rise. As a result of higher energy expenditures, consumers reduce their expenditures on other goods and services. The general rise in all consumer prices depresses real disposable incone further.

Also, with lower asgregate demand and higher production costs, businesses cut back on investment expenditures. In the near-term, investment in oil and gas stroctures and equipment may be expected to increase, and may offiset the loss in non-energy investment. However, the decline in non-energy investment can be expected to dominate beyond the first few years and result in a net capital stock below the Reference Case levels.

Compounding this effect is the prospect that interest rates will rise with inflation, assuming that nominal money supplies remain constant ${ }^{2}$. The resultant reduction in the real money supply

\footnotetext{
${ }^{2}$ The Federal Reserve Board waxy respond with an accommodating policy, sach as a chinge in the anownt of non-borrowed reserves. This analysis, however, assumes that PED policy is unchanged across all cases considered.
} 
initially raises interest rates and may discowrage investment and interest-sensitive components of consumer expenditares such as antomobiles, honsing and other durable purchases.

Export and import markets will also be significantly affected by the higher energy prices. While the prices of goods exported by the U.S. will rise, so too will the prices of imported goods as the world market adjusts to higher world oil prices. A priori, it is difficult to judge whether the nominal trade balance will be reduced or increased as a result of these influences.

How do these interactions play out in the $+\$ 20$ Case? The aggregate results are represented in Figure 9 below. Figure 9A indicates that the potential ontput of the economy falls at an increasing rate through 2005, when the maximum price increase above the $A E O 96$ Reference Case is achieved. After that point the price differential is maintained, yet the economy continues to lose its capability to produce maximum output. The measure of the potential output of the cconomy approaches a long-term equilibrium at a point below the Reference Case path, which will occur sometime in the post 2015 period. By 2015 , the loss in potential ontput is approximately $\$ 75$ billion.

However, in achieving this long-term equilibrium path, the economy will incur substantial adjustment costs. The best way to view the second line in the chart is to consider the Real GDP impact as having two components -- the loss in potential and the adjustment costs of achieving the new equilibrium path. Hence the real GDP loss reaches just over $\$ 100$ billion by 2005 when the target price difference is attained. Thereafter, the economy begins to stabilize at a loss of approximately $\$ 110$ billion and is beginning to move back to the Reference Case somewhat. The expectation in a longer nun setting past 2015 is that the loss in real ourput for the economy will approach the ame trajectory as the loss in potential output. In essence, the adjustment component of the impact will have played out as the economy works out the shori-term effects and settles into its long-run path.

The components of real GDP change are shown in Figure 9B. Consumption and investment fall through 2005 in response to highes energy prices. Consumption is lower by nearly $\$ 85$ billion in 2005 and remains below the Reference Case at his level through 2015. Investment falls by $\$ 36$ billion in 2005, recovers by a little, then declines to $\$ 39$ billion down in 2015. As expected, however, the net real trate balance is higher, as higher world oil prices create a greater claim on the output of the U.S. economy.

Wealth Effects. The effects above identify the impacts on the economy to produce output, as measured in the aggregate by Gross Domestic Product. However, the rise in energy prices not only affects what we produce, but what we have available for domestic use, both in terms of domestic consumption and the resources available to expand the productive capacity of the U.S. economy. Essentially, higher oil prices represent a transfer of wealth within the domestic economy and to $\mathrm{OPEC}$ and other oil producing nations.

The Impacts on U.S. Energy Martets and the Ecenomy of Reducing Oil Imports Energ Isforration Administration, September 1996 


\section{Figure 9A. Losses to the U.S. Economy $+\$ 20$ Case}

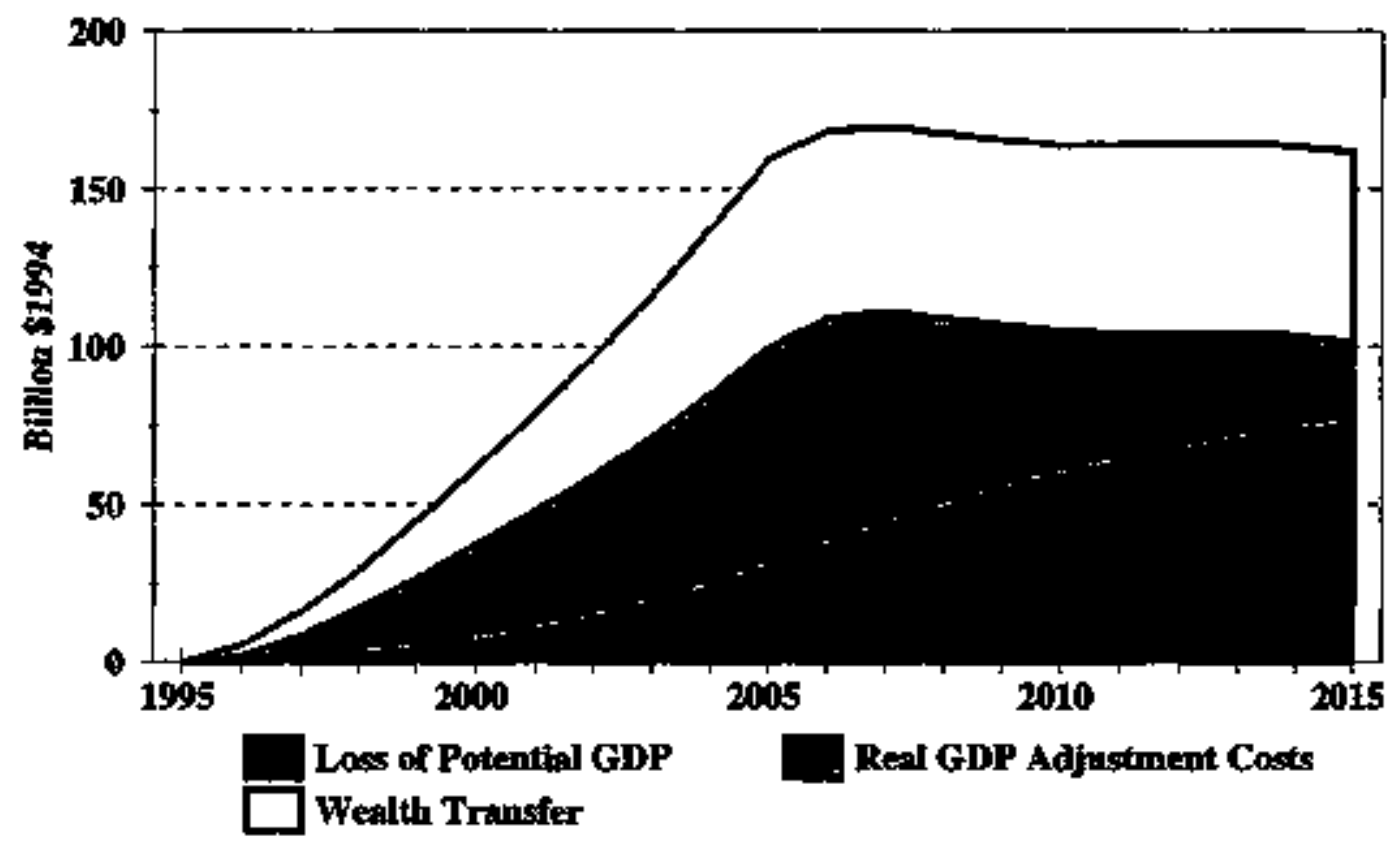

\section{Figure 9B. Components of Real GDP Change from Base, $+\$ 20$ Case}

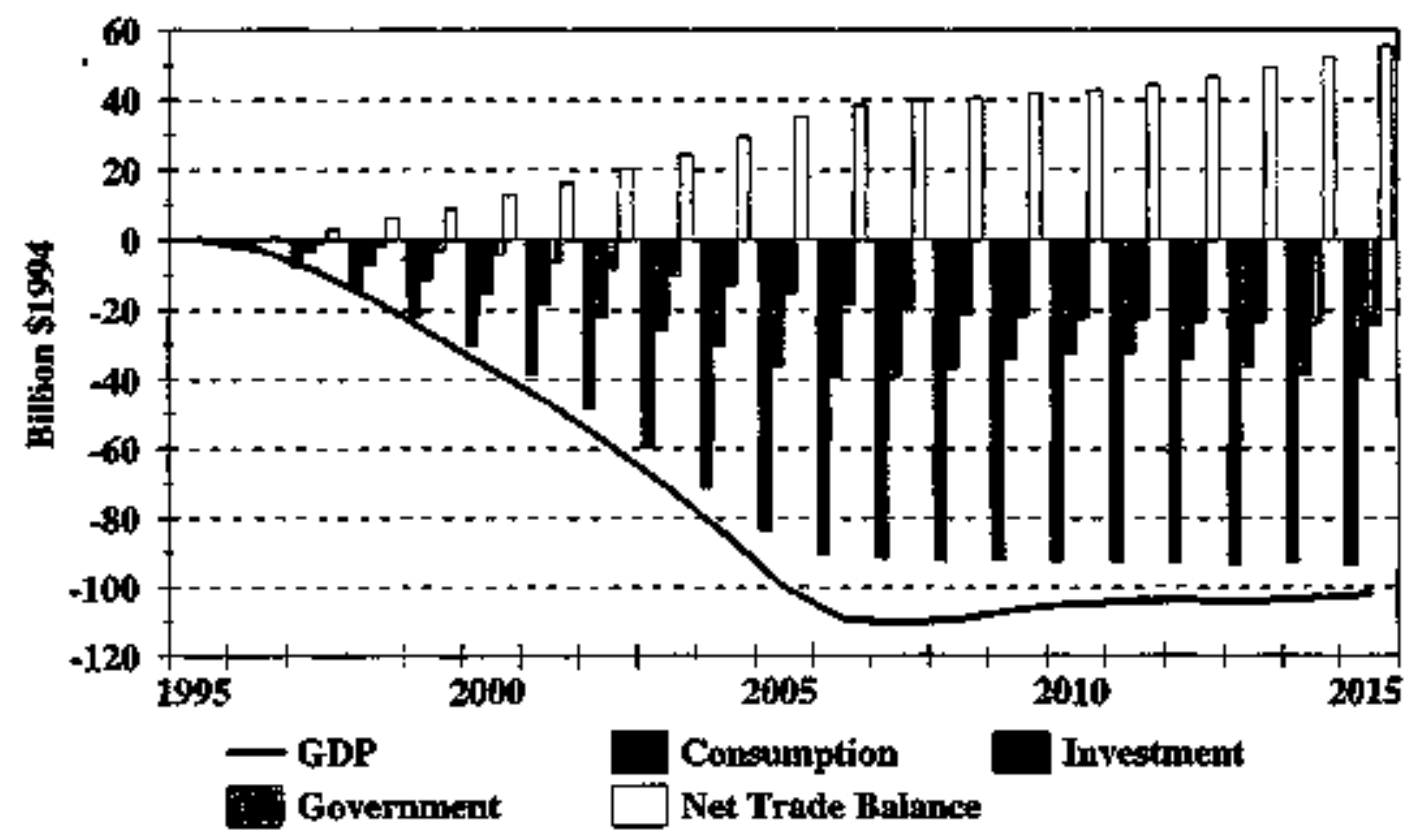

The Impacts on US. Energy Markets and the Econongy of Reduciag Oil Imports Rnergy Information Administration, September 1996 
It is possible to envision a set-of accommodaring monetary policies that might be able to fully mitigate any loss in output in the economy from higher world oil prices and to produce exactly the same output as before. Yet the economy will be fundamentally worse off because the oil price increase reduces the quantity of foreign goods and services the country can purchase with proceeds from any given quantity of our exports. Ultimately exports must go up to pay for the more expensive oil, while domestic consumption, and investment, will fall. The wealth loss thus represents claims on U.S. goods and services by foreign producers of oil. The calculation of the wealth transfer is straightforward. Simply maltiply the new world oil price minus the Reference Case price level times the volume of crude oil and petroleum products imported for each year. The calculated wealth transfer rises to approximately $\$ 50$ billion in 2005 and remains at this differential throughout the forecast period.

\section{Inpacts os Sectors of the Economy}

When the world oil price increases $+\$ 20$ relative to the Reference Case, all prices throughout the economy are higher because of increased production costs and the economy suffers real outpot losses. If the economic impacts of the increased world oil price are examined by sector, few sectors enjoy increased activity. Mining, since oil and gas mining is an important part of that sector, experiences ontput gains over the entire forecast period. However the output loss in the rest of the economy far outweighs the gain in this sector (Figure 10). Construction, wholesale and retail trade, and services are impacted relatively more than the manufacturing sector with increased prices and interest rates following the higher world oil prices. Residential irvestment is more sensitive to interest rate changes and experiences farger percentage losses. As a result, industrial output more dependent on residential investment and consumption experience relatively larger output losses. However, the differences in percentage losses among these sectors are small. In terms of dollar output loss, the manufacturing sector is the hardest hit industrial sector when oil prices remain high.

Within the manufacturing sector, transportation, refining, chemicals, and stone, clay and glass industries are among the manufacturing sectors that experience relatively higher percentage losses relative to the manufacturing sector as a whole. In addition, furniture and lumber industries are hit harder by output losses, reflecting residential investment and consumption losses in the aggregate economy. On average, the manufacnuring sector experiences its greatest percent loss in output by 2005 , reaching just over 1.0 percent. As the econony begins to experience less output loss by 2015 , so does the manufacturing sector. 

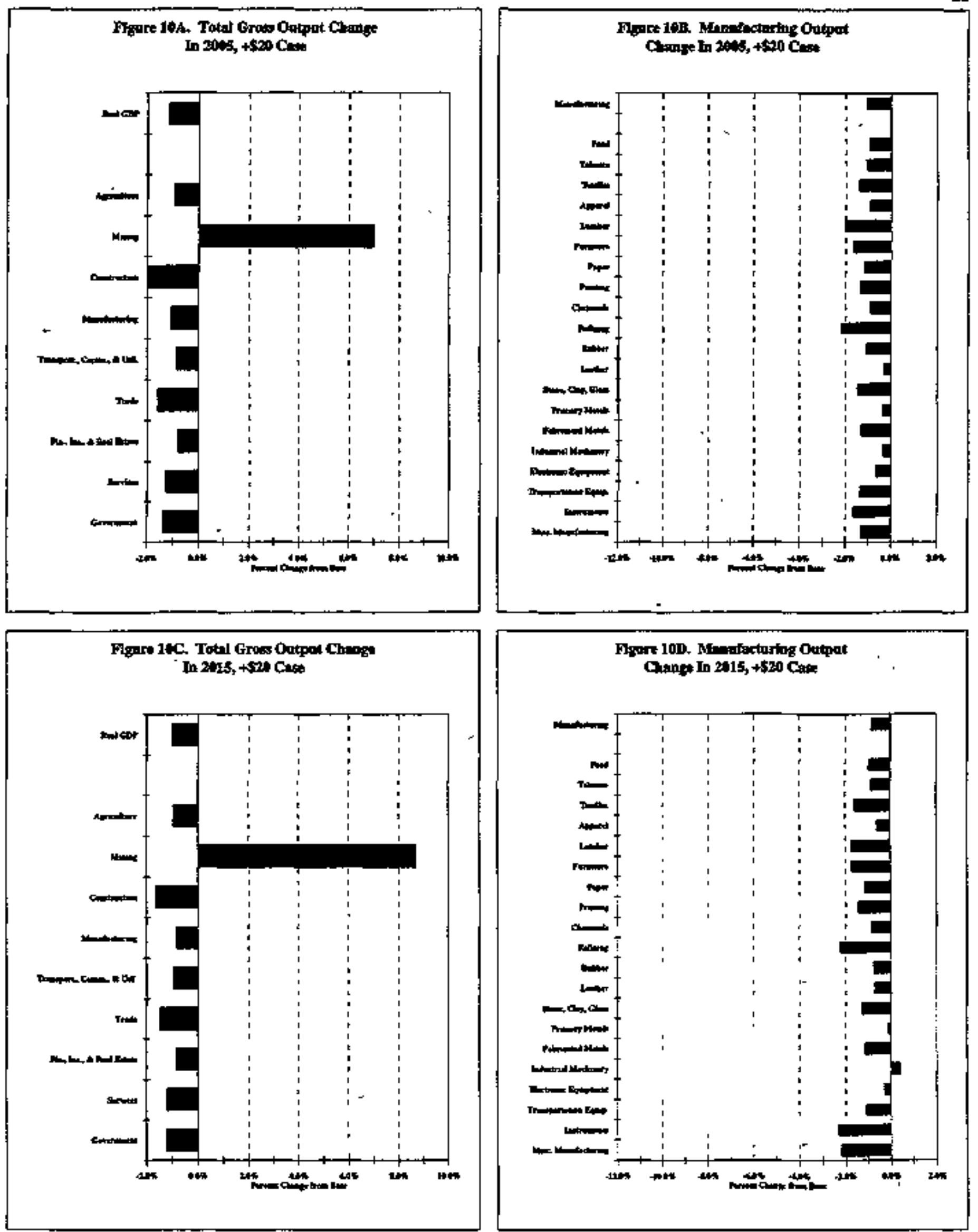

The Inpacts on U.S. Entrigy Murkets and the Economy of Retucing OII fonports Energy information Aduratatration, September 1996 

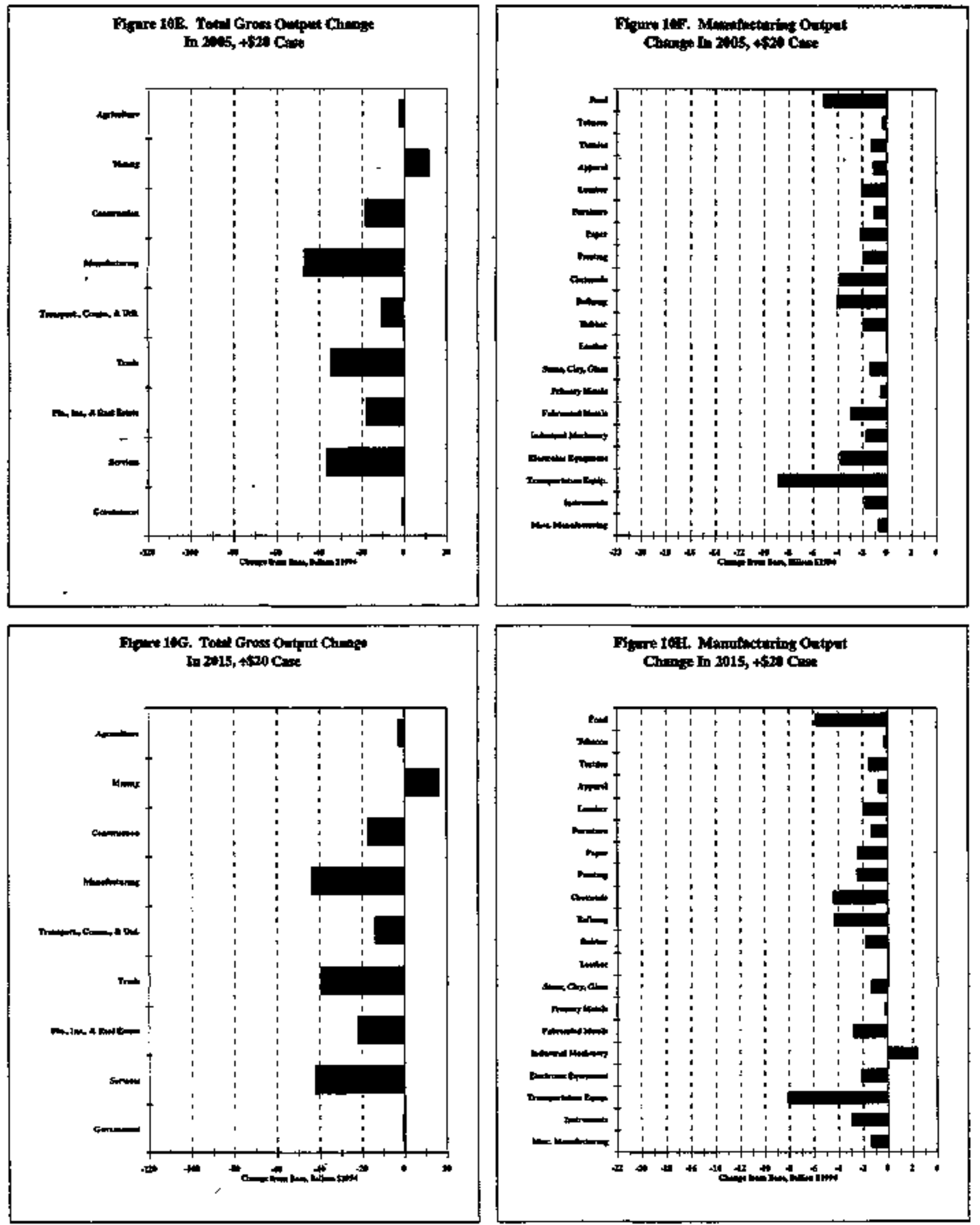

The Impacts on US. Energy Martets aed the Economy of Reducing Oit finports

Bnergy Information Adnipistration, September 1996 


\section{The Imposition of an Oil Import Fee}

Imposing an oil import fee to reduce oil imports results in the collection of substantial revenues. How these funds are used has important macroeconomic effects. In addition, under a fee, the U.S. experiences a price wedge between the now higher price of U.S. exported goods relative to fortign imported non-energy goods. This price wedge will have impacts on the U.S. net trade balance and the aggregate econony. These two issues will be discussed in tum.

\section{How Wall the U.S. Government Use the Collected Revenues?}

In assessing the impact of an oil import fee on the economy, the fundamental price increase dynamics (as discussed above in the section on rising world oil prices) still hold. Namely, higher energy prices raise the aggregate price level of the economy, lower real disposable incone, and raise interest rates. All of these effects contribute to a loss in real ouput for the economy. However, one fundamental diffenence occurs -- funds are generated through the collection of the $\mathrm{fee}$ and in the case considered is projected to collect $\$ 1.3$ trillion in tax revenues over the next 20 years. From a policy perspective a fundamental choice needs to be made: are the collected revenues used to reduce the Foderal deficit or are they recycled back to the economy through a tax reduction elsewhere. If the choice is to recycle the funds, there are additional options: reduce corporate or personal income taxes; reduce the employee-or exployer-paid portions of payroll taxes; and renew and increase investment tax credits or R\&D credits. Each option yields different profiles of economic activity, though there are similarities among some of the options.

For this study two cases are investigated. In the Deficit Reduction mode, the gross collections from the imposition of the fee raise Federal indirect business tax revenues, and these additional revenues are assumed to be used to reduce the deficit. This highlights the effects on the economy of the price shock imposed by implementation of the fee. In the Deficit Neutral mode, the gross revenues are not used to reduce the Federal deficit. The simulation explicitly targets "full employment Federal deficit" to remain the same as the Reference Case (the path forecast when there is no fee) throughout the forecast period. The renm of the energy tax revenues is accomplished through a reduction in the paynoll tax rate, both the employee and the employer shares.

Deficit Reduction. The effect of higher energy prices on the aggregate price level is to drive up near-term nominal interest rates. The rise in interest rates helps to discourage investment and interest-rate sensitive components of consumer expenditures such as automobiles, housing and other durable purchases. However, in the longer-term, as price intlation in the economy abates, the continuing reduction in Federal government borrowing serves to moderate the adverse impacts on interest rates relative to the Reference Case (Figure 11A). Figure I1B shows the impacts on the output of the economy. Both consumption and investment are driven down in

The Inipects on U.S. Energy Markets and the Economy of Reduchig Oit Imports Baverey Informattion Administration, September 1996 


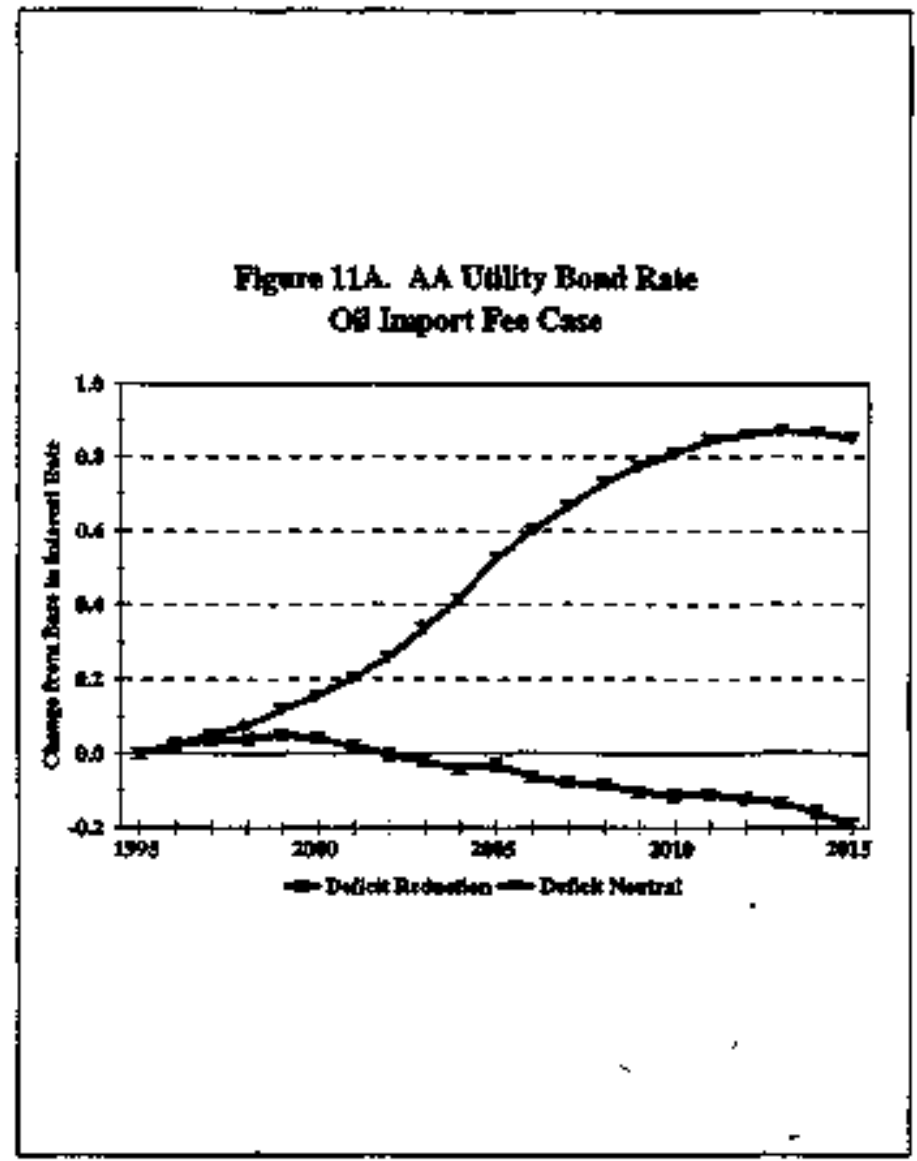

Flgure 11B. Components of Real GDP

Onl Import Fee, Deffít Reduction

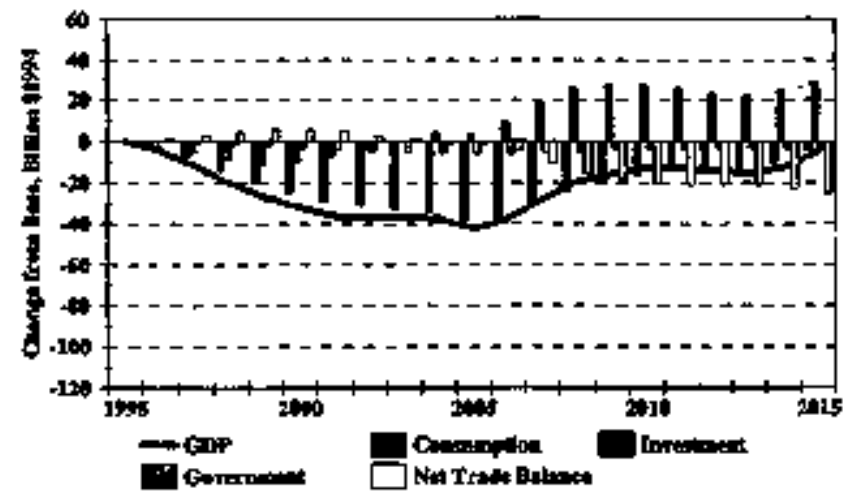

Figure 11C. Components of Real for Odl Impart Fee, Dellidt Neutral

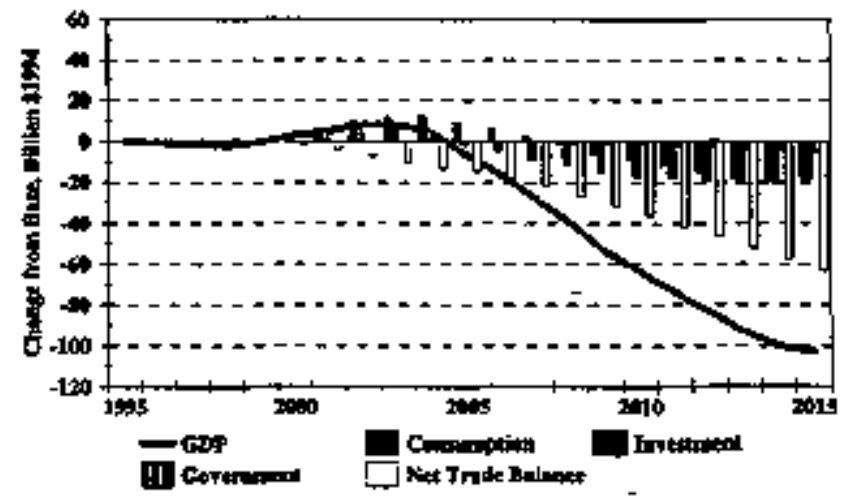


response to higher energy prices, and higher interest rates, particularly in the near-term through 2000. However, after 2000 , investment in the economy begins to tum around given the impact of lower interest fates, and leads the recovery in the whole economy. By 2015 , real GDP has almost recovered to the Reference Case value of output.

In the deficit reduction case, most of the sectors of the economy suffer output losses until 2005, (Figure 12). By 2015, when GDP has recovered about back to the Reference Case, sectoral output recovers also. The mining and construction sectors follow a different pantern. The increase in both 2005 and 2015 in oil and gas mining reflects domestic oil and gas production, which has increased 14 percent relative to base in response to the higher oil prices brought on by the Import Fee case. Eariy in the forecast period, the construction sector is positively affected by changes in investrent, principally associated with mining and petroleum structures brought on by higher prices for domestic oil. ${ }^{3}$ Later in the forecast period, with interest rates falling relative to the Reference Case, investment in structures, both residential and non-residential, resuls in an increase in construction activity.

Deficit Neutral. Almost the exact opposite set of dynamics play out in the deficit neutral case. Hene, the objective is to return funds to consumers and basiness in order to ameliomate the adverse impacts on the economy associated with higher energy prices. Reducing employee-paid payroll taxes replace the purchasing power drained by the oil import fee. The restoration of income increases the inflationary aspects of the policy. In reaction, interest rates rise and evenually investment suffers. Employee-paid payroll tax reductions support consunption at the expense of lower business investment and construction (curtailed by higher interest rates). Employer-paid payroll tax cuts would offset the higher energy costs from the oil import fee. Reductions in the employer-paid payroll tax would lower costs for labor, offsetting some of the energy price increases by encouraging business to substitute lower-priced domestic labor for higher-priced imported energy. However, none of the deficit neutral approaches relieve longnun federal pressure on the credit markets. This means that interest rates remain high and the Ameliorating ímpacts of lower employee costs through reduced employer-paid paysoll taxes are overshadowed by continuing increases in energy prices and overall prices in the economy.

While this policy does essentially wipe out any near-term effect, actually raising real GDP in some years, the post-2005 period suffers (Figure 11C). Lower investment translates into smaller increases in productive capital stock and lower output potential. As GDP begins to fall due to increasing pressure on interest rates and prices, ousput in most sectors of the economy begins to fall as well (Figure 13). The mining sector remains above its Reference Case levels throughout

\footnotetext{
The DRI Macro Model cortains an equation for potential ouprat and is specified as a function of capital, labor, encrgy and R\&D. The energy concept currenty is represented as domestic energy production of oil and narutal gas. In previous versions total energy demand was used. The specification of this equation is undergoing teview by DRI. In this study for GAO. EIA temoved domestic energy production of oil and natural gas as a determinant of movement in the potential GDP equation.
}

The Impacts on U.S. Energy Markets and the Econongy of Redecing Oil buports Energy Information Adatnistration, Septenher 1996 

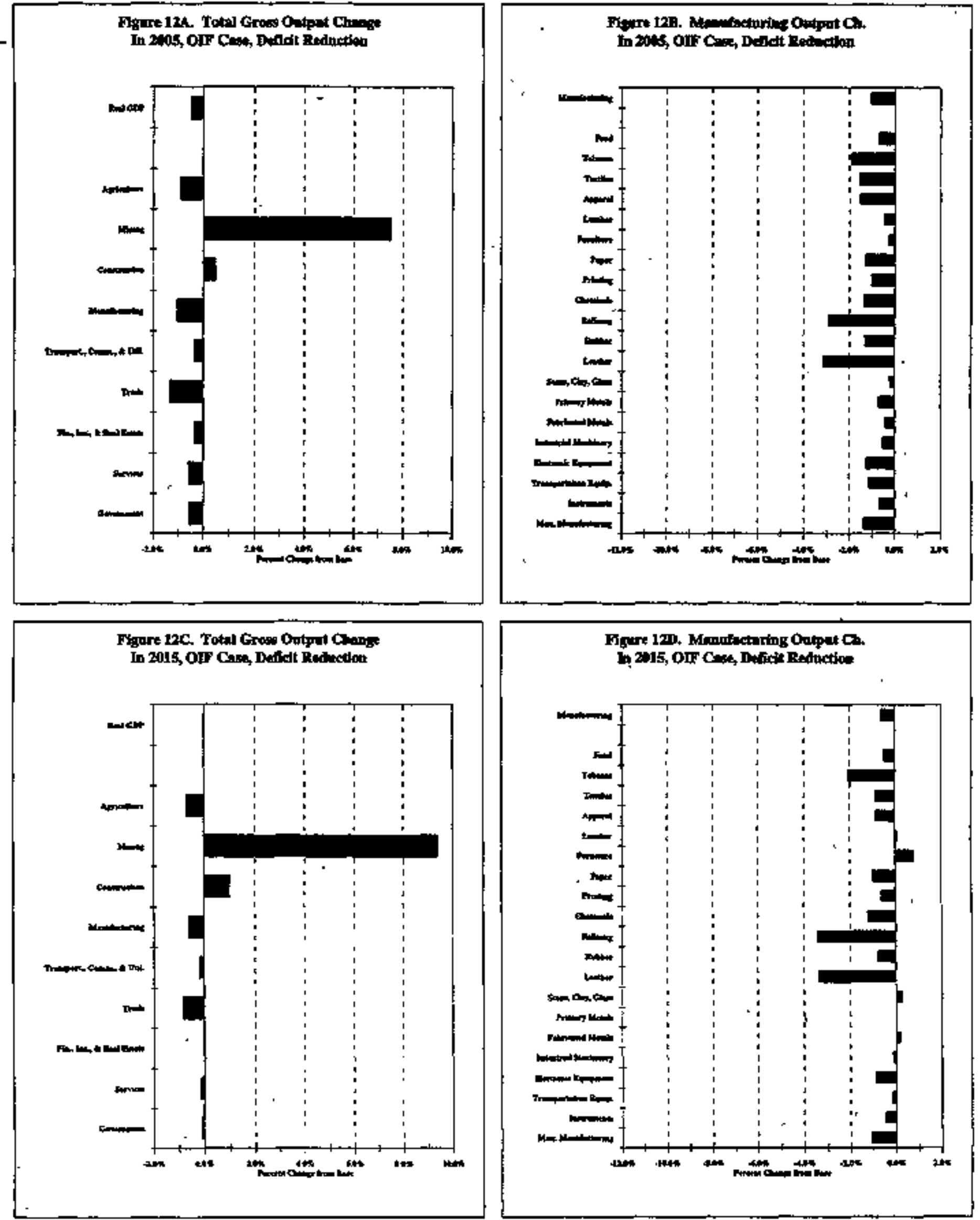

The Impacts on U.S. Energy Markets and the Economy of Reducing O1 Imports Energy Information Administration, Septemher $19 \%$ 

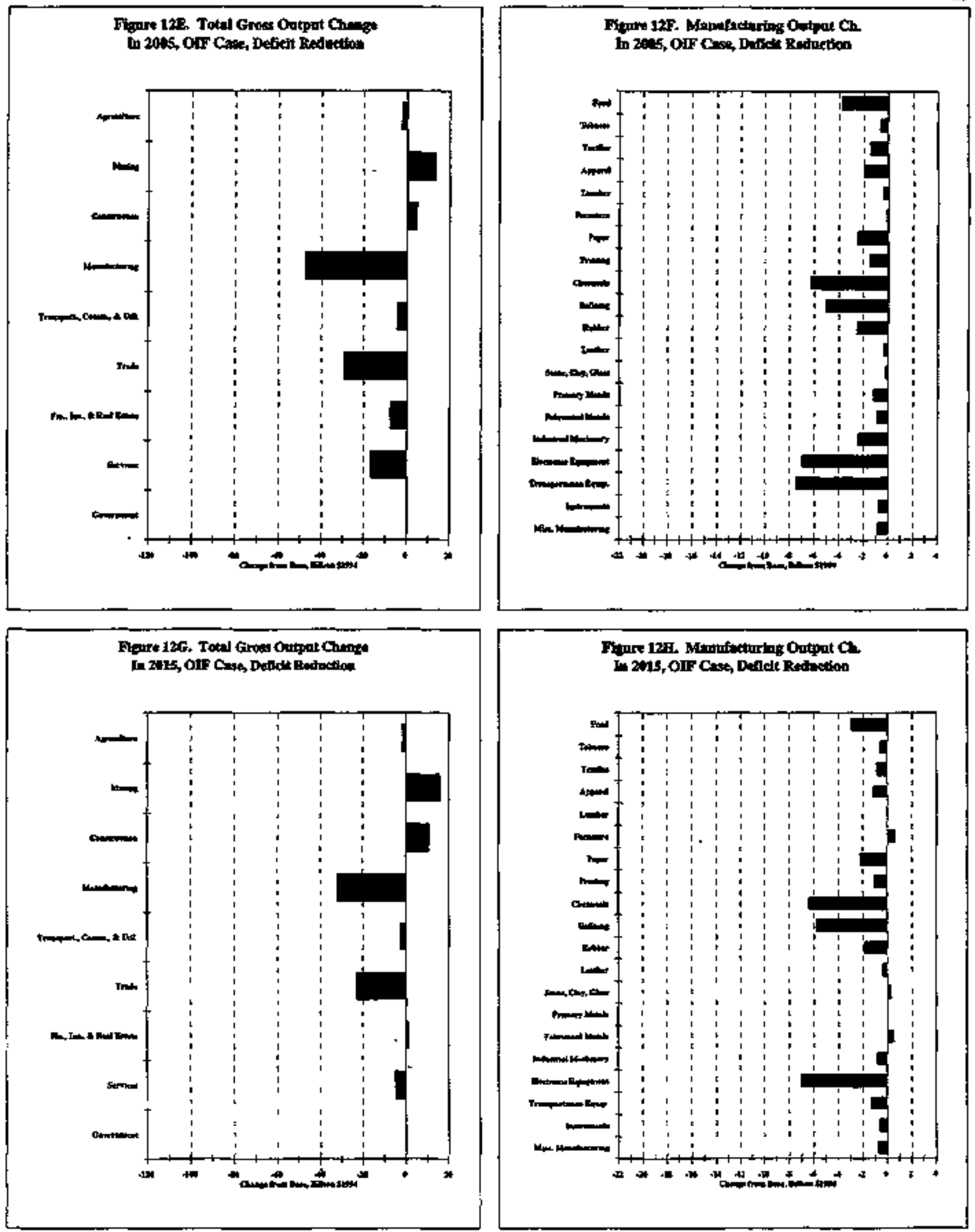

The Impacts on U.S. Energy Markets and the Fcopomy of Reducigg Oil Imports Enersy Information Administrition, September 1996 

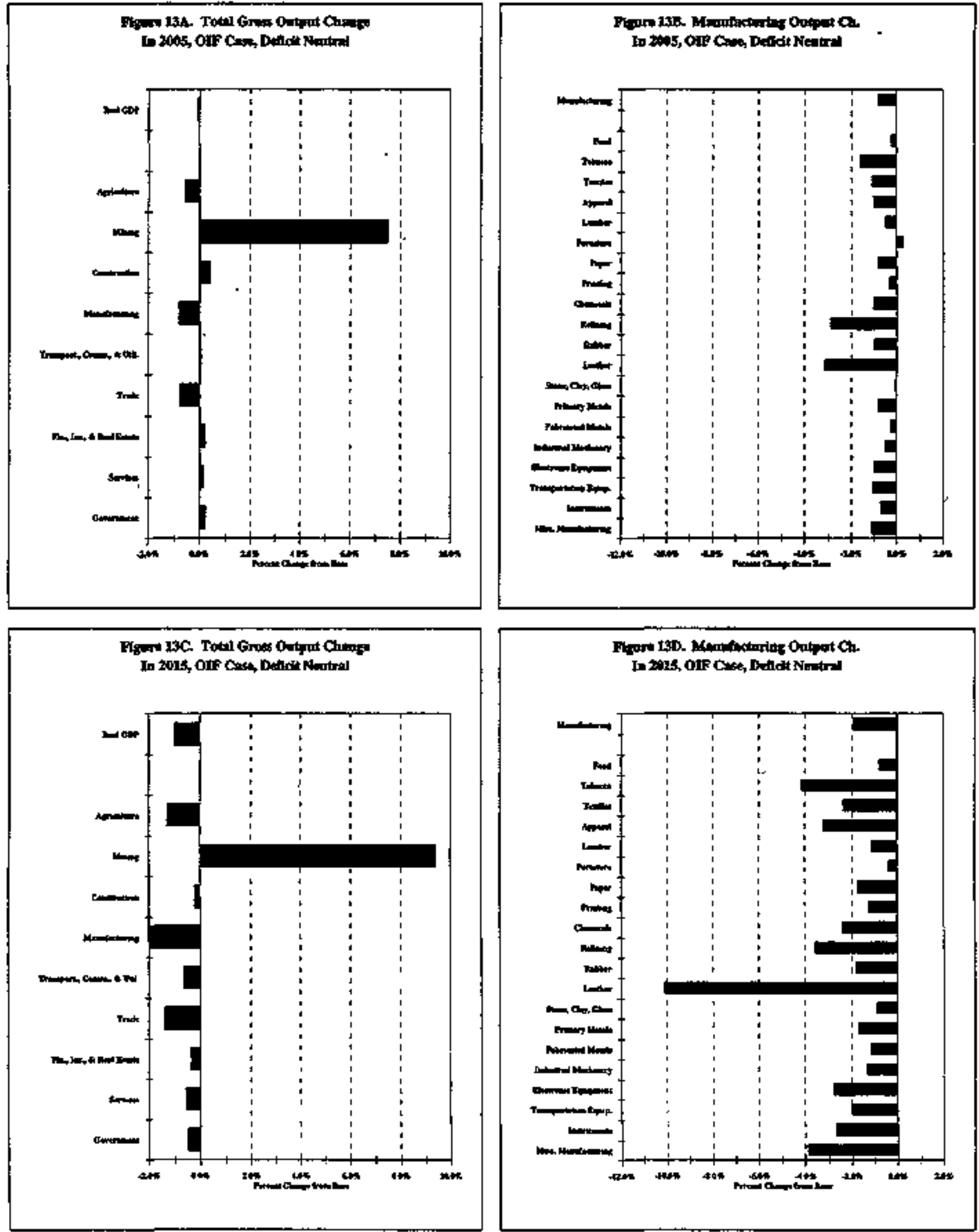

The Impacts on U.S. Enercy Markets nud the Economy of Reducing Oil Imports

Eneray Information Administration, September 1996 

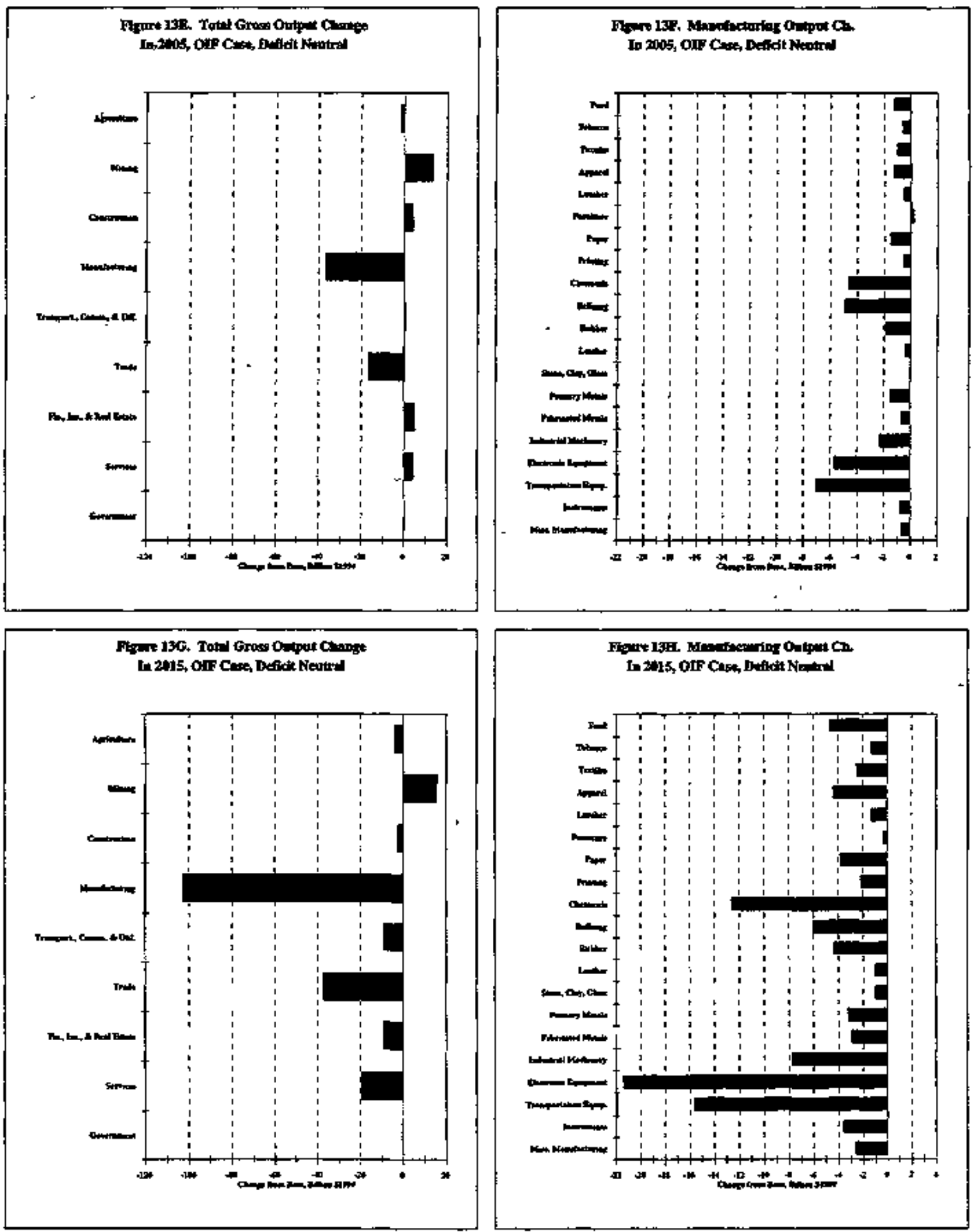

The Impacts on U.S. Energy Morkets and the Economy of Reducing Oil Imports

Energy Information Administration, September 1996 
In comparing the two broad options in the long-term - to recycle or not - cuts in capital costs stimulate more growth than cuts in labor costs. Revenue recycling schemes that favor business investment in the long-term, such as investment tax credits, R\&D credits of cuts in córporate income taxes, shift the economy's aggregate supply curve out more than policies aimed at reducing labor costs. While the labor force will not expand significantly in response to higher after-tax wages, business continues to add productive capital and thus increase the coonorny's potential to produce output when operating costs are reduced, thereby having more of an aggregate supply shift for policies stimulating business investment spending.

\section{How are the Impacts Different than from Hijgher World Oil Prices?}

Atgremate Economy. Higher world oil prices impact all countries, with the increased-energy expenditures from higher world oil prices going to oil-pnoducing nations. All countries face tigher prices through increasing oil prices. The relative impacts actoss countries depend on many factors such as: the importance of oil in the production process; whether a country is oil producer or oil consumer; the bebavior of exchange rates and interest rates in response to increasing world oil prices; and the fiscal and monetary response of each country to increased -prices ${ }^{4}$. This study does not attempt to estimate differential impacts of higher world oil prices on all courtries; however, one fact is unalterably true: with higher world oil prices, all countries experience higher prices. This is not the case when a fee is imposed on U.S. imported oil. Indeed, because of the reduction in U.S. oil demand, the world oil price facing other nations is expected to be lower than in the Reference Case.

Not only are the price effects different, so is the treatment of the increased expenditure from higher oil prices. For the Deficit Reduction Case, the assumption is made that the revenue from the oil import fee is collected by the U.S. government and is used to reduce the deficit. This is in contrast to the situation where funds are transferred to oil producing nations when world oil prices rise. Consurmption and fixed investment of the rest of world changes little from base during the Import Fee Case. When higher world oil prices prevail worldwide, rest of world consumption and fixed investment falls by 2.5 percent relative to base.

Imposing an oil import fee has significant impacts on the U.S. economy, although smaller than in the $+\$ 20$ case (Figure 14A). The economy experiences output losses throughout the 20 year period from 1995 to 2015; however the dynamic pattern of imposing an oil import fee differs substantially from the higher world oil price case. In the Deficis Reduction Import Fee Case, the economy begins to retom to Reference Case by 2005 for two reasons: (1) the revenue from the oil import fee reduces the deficit, leading to quicker recovery in investment because of interest

\footnotetext{
"Both of the oil impoit redietion schemes absrract the inpact of changing exchange rates. For both of these scenarios, it is assumed that exchange tates do not ctivage from the Refentence Case and that the Federal Reserve does not react as a resnlt of increasing proes in either the ofl impart fee or higher world oil price case.
}

The Impexts on US. Enery Markets and the Eonemy of Reiucing Oil Imperts Energy Information Administrathom, Septemper 1996 


\section{Figure 14A. Real GDP Change from Base}

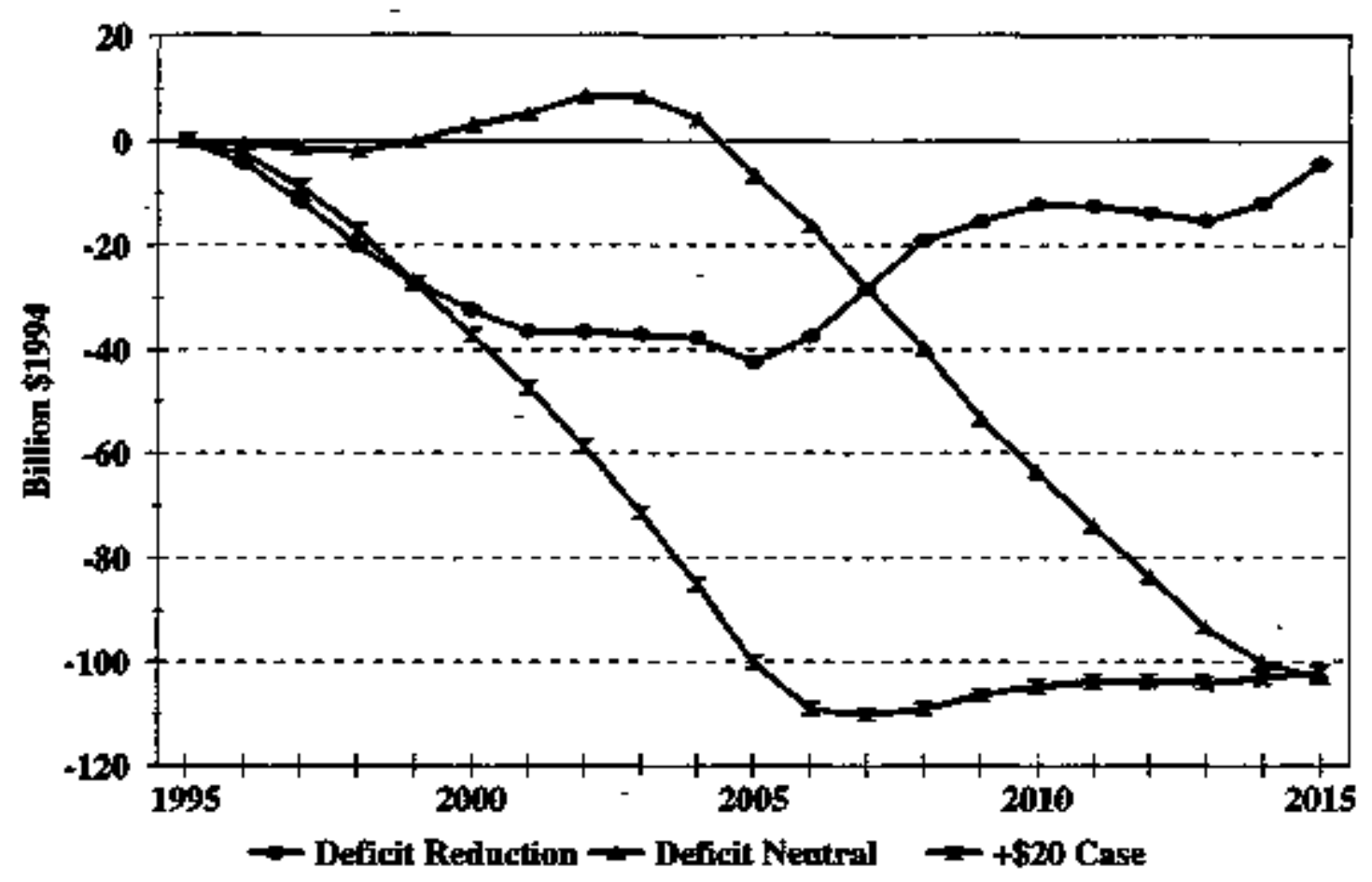

Figure 14B. Terms of Trade

(Price of Exports / Price of Imports)

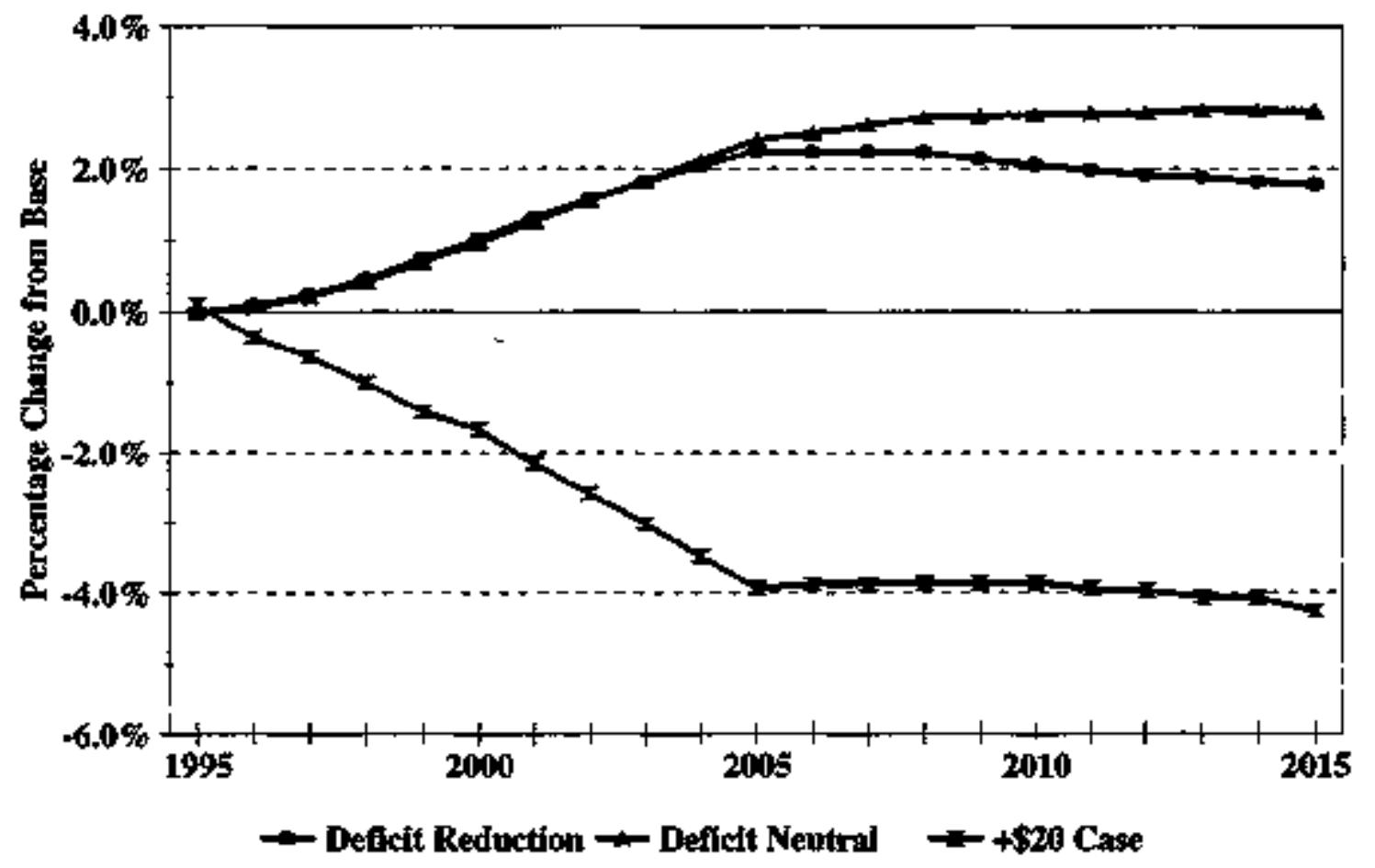

The Inpacts on U.S. Fnergy Markets and the Ecomomy of Reducing On Imports Energy Information Administration, September 1996 
rate impacts, and (2) import prices facing the United States in the oil import fee case fall relative to base, primarily because world oil prices are lower due to the reduction in U.S. oil demand.

The U.S. imports both finished goods, which are purchased directly by consumers, and intermediate goods and equipment, which are purchased by businesses. Imported materials and components are used by U.S. firms in their production processes. Lower import prices for these inpuis restrain the upward pressure on U.S. producers' price increases brought on by the fee. As a consequence, both consumer and wholesale price increases are less in the Import Fee Case than the $\$ \$ 20$ Case as a result of onr trading partuers not facing increases in their oil prices.

Since interest rates, after 2003, are lower in the Deficit Reduction Import Fee Case, investment rebounds much quicker, consumption recovers and the economy's output is close to base by 2015. The net trade balance (real exports minus real imports) remains a negative influence on GDP, since export prices are always above base.

Sectoral Impacts. Differences in sectoral impacts between the two inmort reduction schemes can be traced to differences in impacts of interest rates and prices, as well as the patterns of economic fingl demand losses. In the Import Fee Case, both interest rates and import prices are lower than in the world oil price increase case. Those interest-rate sensitive industries will experience relatively less impact (nommalized for total industrial impact for each case); and those industrial sectors that are either export dependent or have high import penetration will experience relatively larger economic impacts compared to the higher world oil price case. The agrictulure and manufacturing sectors, those sectors more affected by trade, show higher percent change from base relative to the economy's total output percent change from base, while the consuraction sector exhibits lower percent changes compared to total ouput.

The mining sector's outpat gains are very similar between the Import Fee Case and higher world oil price cases, both in terms of time profile of changes and magnitude. The more interest rate and trade sensitive industrial sectors exhibit the greater differences of economic outpot changes.

Within the manufacturing sector, the chemical, apparel, leather, and electronic equipment industries exhibit percent changes from base higher than the overall manufacturing sector's percent impacts for the Import Fee Case. These industries tend to be more trade oriented. The industries affected more by construction, stuch as lumber and stone, clay and glass, experience lower percentage changes relative to total manufacturing sector output in the Import Fee Case.

If one examines these industries' percent changes from base in the higher world oil price case, these statements about relative impacts are reversed. Since import prices and interest rates increase in the higher world oil price case and imports are reduced more relative to base, the trade oriented industries experience lower percentage reductions from base and the consuructionsensitive industries show higher percentage reductions from base compared to manufacturing.

The Impacts on U.S. Enerzy Martets and the Economy of Reducing Oil Inports Energy Information Administration, Septenber $19 \%$ 
The miming sector (which includes oil and gas mining) is the clear winner in terms of changes in either output or employment resulting from the imposition of an oil impart fee, regardless of whether the money collected is used to reduce the deficit or to allow the social security tax rate to be redoced in order to insure deficit neutrality.

Imposing an oil import fee is aot costless to the manufacturing sector. If one focuses on percent losses in 2005 (close to the largest loss in GDP), most industries show between 1 to $2 \%$ loss in real output. Most of the dollar amount of output lost in that year is concentrated in four industries: transportation equipment, chemicals, food and elecronics. These sectors have a large share of total gross output, so small percent losses in these industries mean larger dollar change in output The general results do not change significandy if employment rather than output is exarmined. Certain industries, such as industrial machincry and fabticated metals, show smaller employment losses (in percentage terms) than output losses, but the overall conciusions of the impacts of imposing an import fee remain the same whether employment or output is used

\section{How Do Flexible Exchange Rates and Monetary Policy Afiect the Results?}

All of the macroeconomic impacts described so far have used the same two assumptions: (1) the exchange rate remains at baseline leveis and (2) there is no Federal Reserve reaction to any change in energy prices resulting from either an import fee or higher world oil prices. The following section reponts resples if these two assumptions are relaxed. The DRI model has exchange rate and a Foderal Reserve reaction function equations that respond to differential ' infliation and interest rates. The exchange rate responds to international differences in inflation, interest rates, trade deficits, and capital flows between the United States and its competitors. The Federal Reserve reaction function looks at the cradeoff beween incteased inflation and unemployment and will change the key federal funds rate depending on this tradeoff. The connomic impacts will vary, depending on which of the assumptions are relaxed. There experiments are described in the following section and the GDP impacts are shown in Figure 15. Each experiment investigates both the deficit reduction and deficit neutral cases of the oil import fee:

1. Assume that neither the exchange rate nor the Federal Reserve reaction equations are operating (the methodology used in the simulations reported earlier);

2. Assume that the exchange rate equation is operating but not the Federal Reserve reaction function; and

3. Assome that both the exchange rate and Federal Reserve reaction equations are operating.

The Inpacts on U.S. Energy Markets and the Economy of Reducing OA Imports Energy Inform:tion Administration, September 1996 
A U.S. imposed oil import fee raises domestic interest rates and inflation. Both of these influence the magnitude and direction of movement in the exchange rate. Higher interest rates canse the exchange rate to appreciate as foreign capital flows to the U.S. economy. However, higher inflation and lower U.S. economic activity tend to cause the exchange rate to depreciate. The GDP impacts of changing exchange rates ulimately depend on the price elasticity of demand for both imports and exports, and how fast markets react to changing intemational prices. The exchange rate for Case 2 first appreciates early in the forecast period and the U.S. GDP impacts initially worsen. Then as prices in the U.S., the exchange rate depreciates leading to amelioration of the GDP losses as export demand recovers.

When the Federal Reserve reaction function is operating through interest rate variation, income losses associated with adverse exchange rate behavior is moderated early in the forecast. The Federal Reserve reaction decreases interest rates, leading to a more rapid exchange rate depreciation and a quicker boost to U.S. export demand compared to the case where only exchange rate variations occur. In the deficit reduction case, where both the exchange rate and Federal Reserve reaction function are operating, the exchange rates devalue throughout the forecast interval. This is because real interest rates are below base case levels for most of the forecast interval, as the Federal Reserve pursues policy to stimulate increases in aggregate demand.

How well the Federal Reserve reaction function ameliorates GDP losses depends on the tradeoff between increased inflation and increased unemployment forecast in each simulation. In the deficit reduction case, inflation is high and unemployment increases. Given both conditions, the Federal Reserve reaction function works to amelionate real GDP impacts by reducing interest rates. However, in the deficit neutral case, higher inflation is the primary concern since atverse employment changes have already been minimized by rebating collected taxes back to consumets and business. The Federal Reserve thus tries to contain inflationary prospects in the economy by raising interest rates, thereby making the real GDP impacts worse early in the period. 


\section{Figure 15A. Real GDP, Change from Base Sensitivity Analysis}

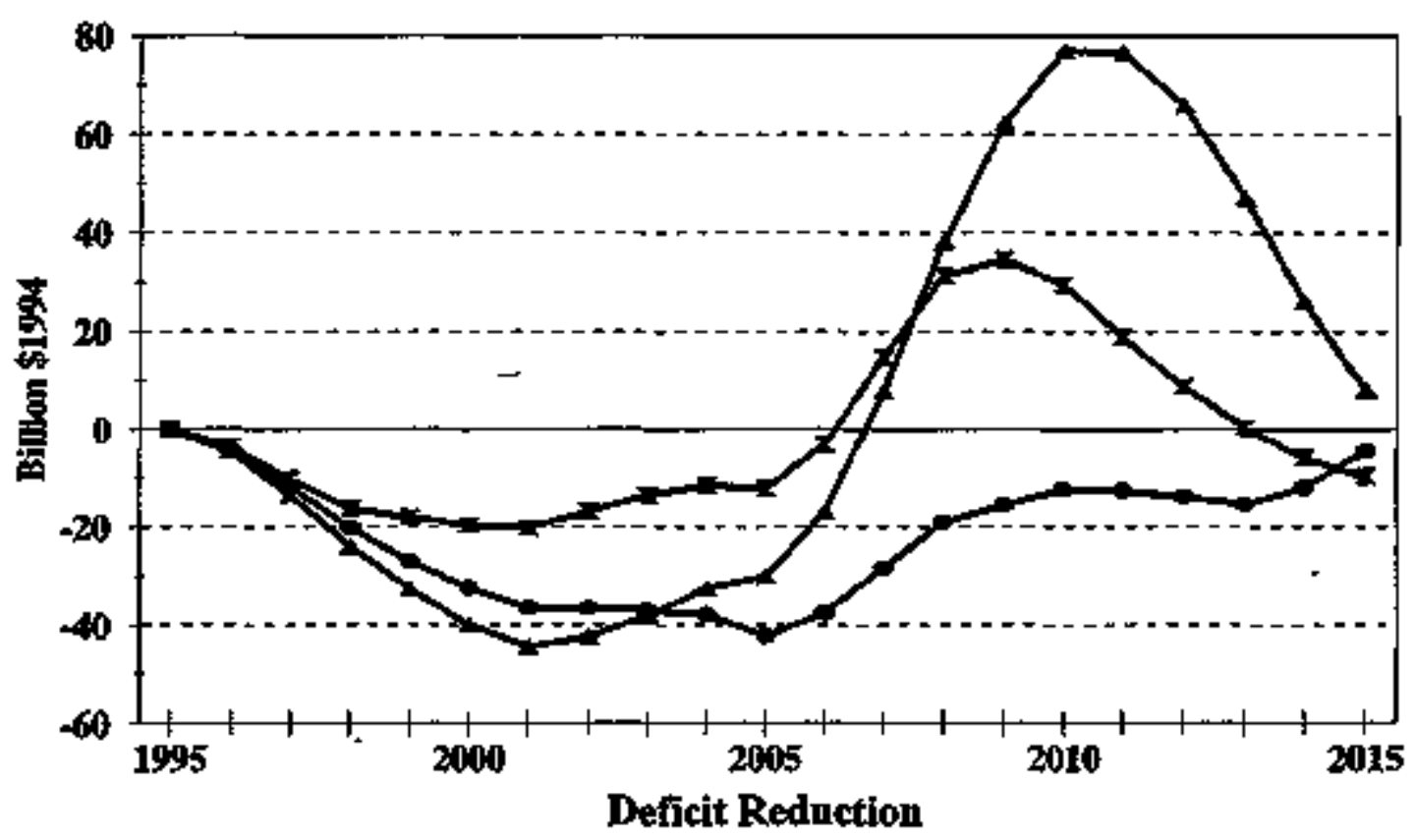

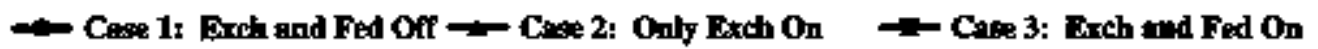

\section{Figure 15B. Real GDP, Change from Base Sensitivity Analysis}

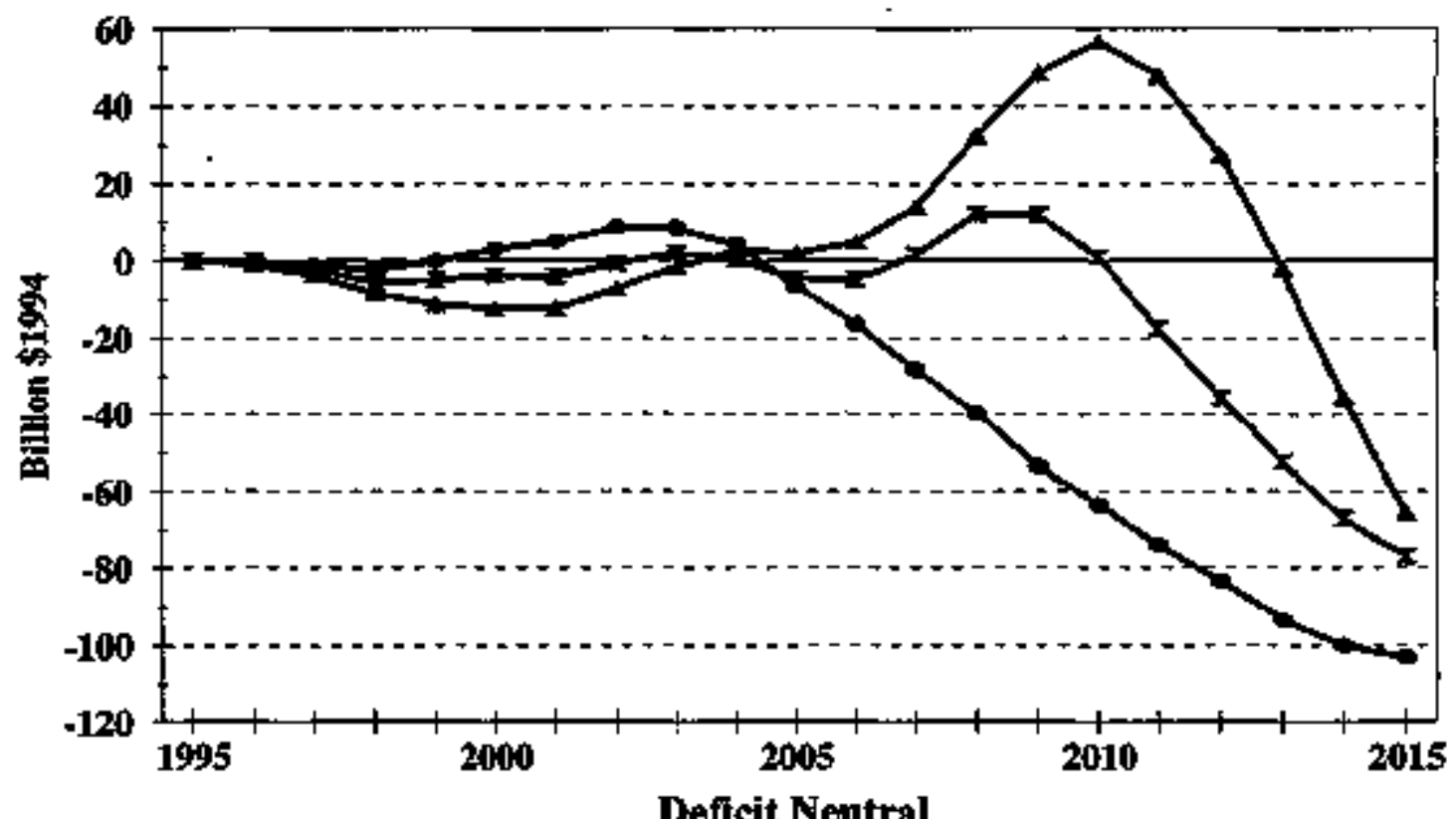

$\rightarrow$ Case 1: Erch and Fed Or - Case 2: Ondy Erch On $\quad-$ Case 3: Exch and Fed On

The Impacts on US. Energy Mintrets and the Bconomy of Reducing Os Imports Enert Informetion Administration, September 1996 


\section{Appendix}

\section{Letter of Request for Study from the Generd Accounting Office}




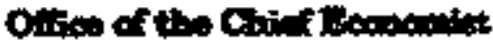

February 23, 1996

Mary Entzilex

Director, Office of Integrated Analysis and Fonecasting

Eneroy Information Administration

ET-80

1000 Independence Aveme, SW

Waslington, DC 20585

Sent by fax to: 202-586-3045

Dear Mr. Hutvder,

In prepartidon for our meeting Dext Wednesday, February $28,19 \%$ at 1.00 in your office, I em sepding this letter to further define our request for assistance from E1A. The purpose of that meeting witl be to fimalize orr tequest

First, I am pleased to report that Representative John Kasich, Chair of the House Budget Committee formitly requested our woik. Along with this letter, I am sending you a copy of our request from him.

GAO requests that ElA use NEMS to estimate the cost to the U.S. econony of redacing oil imports by focusing on the following paraneters.

Policy Jnstruments: We propose two approaches to estinnutipg the cost of cocreased imports.

First, becesuse of tits efficiency in reducing imports, we propose an impont tariff staficlent to reduce imports by 1 mimbd, 2 mmbd, and 3 mabd. Recognizing the efffictity of estimatiog import reduetions, rather than torifi lovels, we have limitod our request to three import rechuction kevels. In wech of these scenarios, the tariff should be phesed in over $: 10$ yeut period in oxder to minimize transition costs. Let me emphasize that we chose th import triff becesuse it is efficient at reducing inports, not bectuse we endorse it as a policy option.

Second, we request a "policy-free" high oil price trajectory, similar to

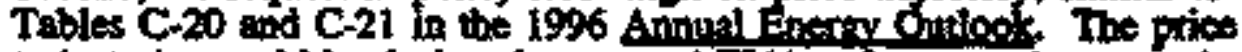
trojectories could be desipped to exceed EIA's reference price scenario by $\$ 5 \% b b$, \$10bbl, \$15/bbl \$20/bol after a 10 year period The purpose of these scenarios is to measure the cosi 60 the U.S. econowny of bigher prices, and the associsted import reduction, withoot focesing on any perticular policy option.

For both approcthes, we stugest thet the results be compared with baseline sectarios abnailly through 2015 .

NAFA and WTO: We propose that these frow-trede arreements remaril in force when entimating the cost of import reductions. However, we wish to 
assume that Canada and Mexico impose an import tarifi of equal magnitude to the U.S. tarift U.S. mentuership in WTO should not alter the scematios beculse it is our undenstanding that membership does not prectude an import taiff on crude oil.

Reverues: We propose that the impest of dlemative tariffs be estimand for

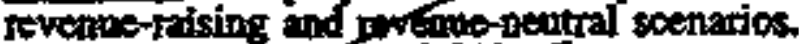

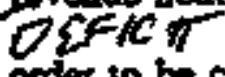

Discount Retes: in order to be consisterit with GAO policy, we would atk that future cost and revenre streams be discomted at a nomins rote equivalest to the yield on govermment bonds that matros at the end of the study proiod. (By inplication, teal disconat rates would be detemined by subtracting estimatus of inflation from the governintot borrowing rite)

GAO is laterestad in the effect of these scenarios on macroeconomic vuriables such as the GDP, the inflation rate, interest tates, omployment and unemployment, batance of payments, and epersy prioes.

I lock forward to on meeting next week, and woukt like to thank you abin for your assistance on this project.

Sincertly.

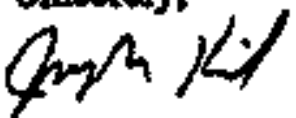

Joseph Kile, Ph.D.

- Senior Economist 


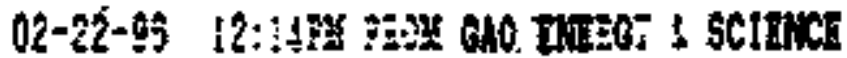
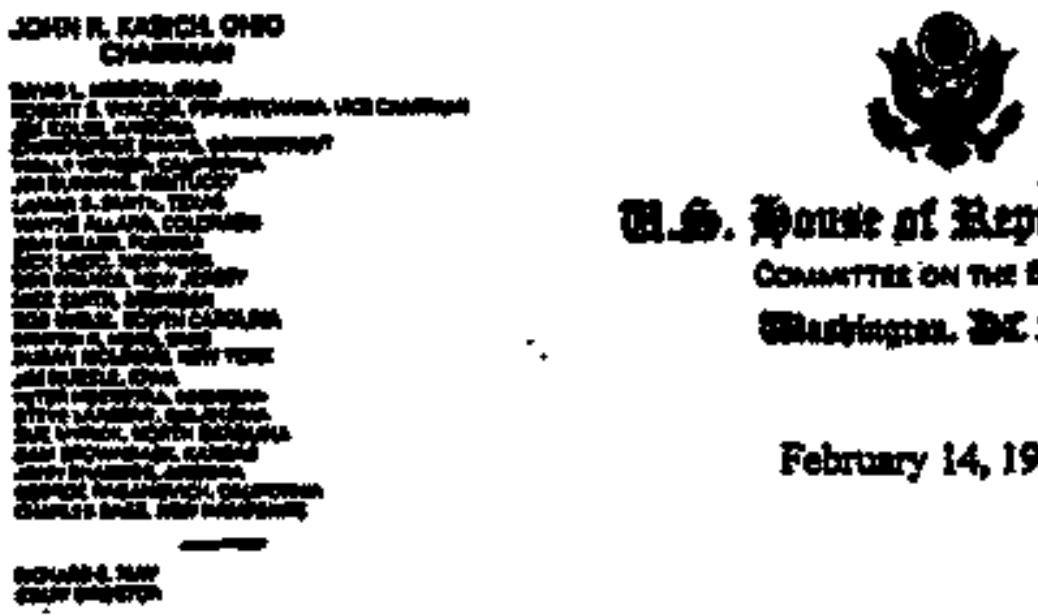

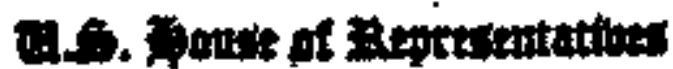

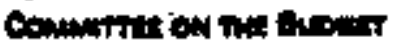

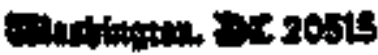

Febrongy 14, 1996

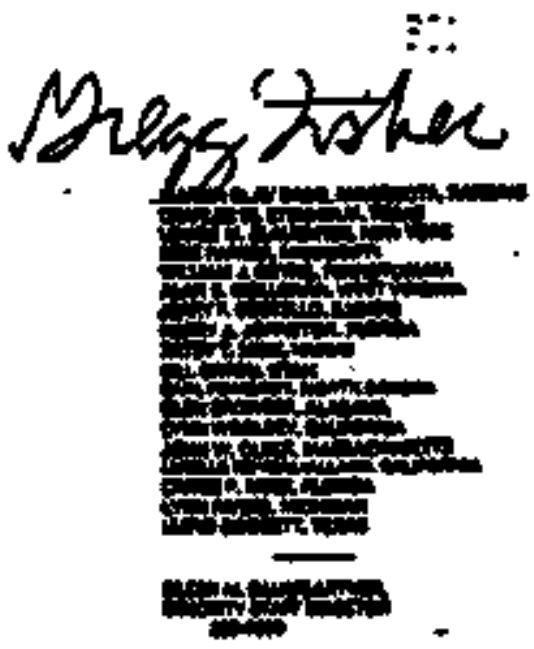

$96-0571$

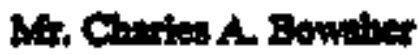

Comprottor Gomel

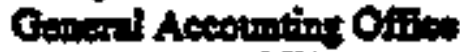

210 Buesh Nit.

Woulingtor, DC. 20548

Dear Mr. Bownher.

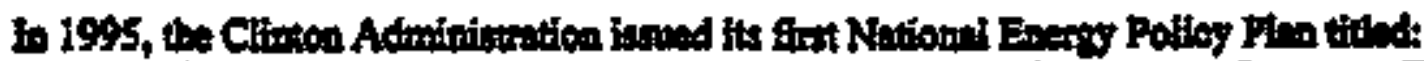

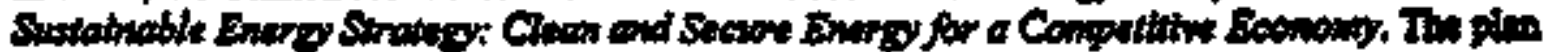

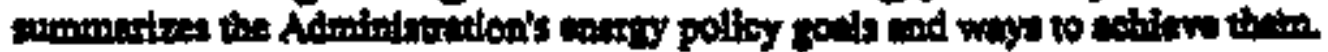

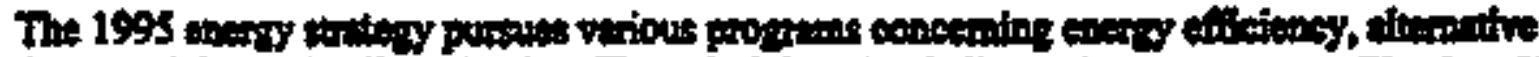

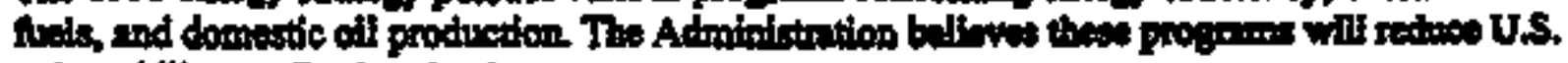

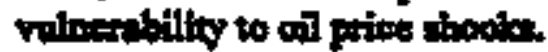

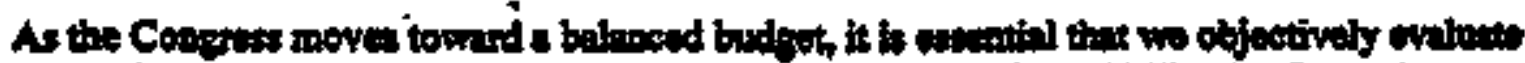

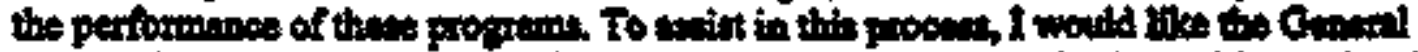

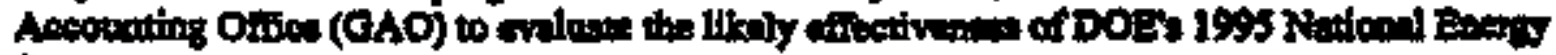
strong.

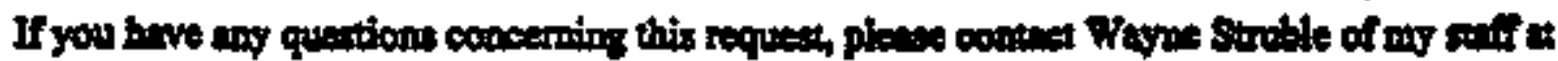

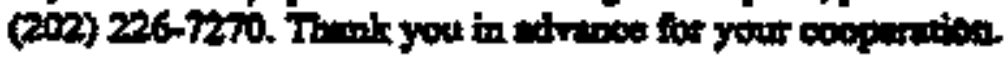

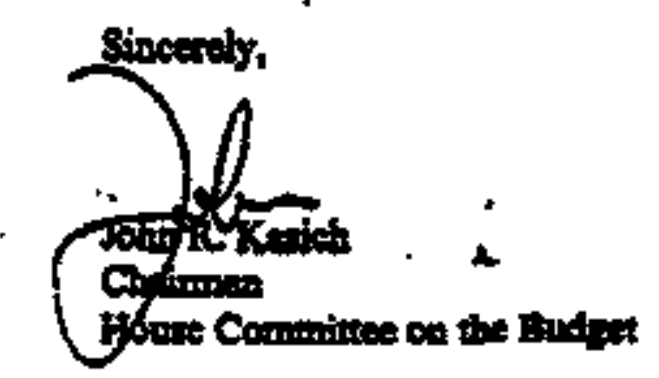

